TOMASZ SZUBERT

Wiedeń

\title{
KILKA FAKTÓW Z ŻYCIA JAKUBA SZELI*
}

W 2006 r. Adam Bartosz, opisując dzieje zapomnianego obelisku upamiętniającego rzeź panów w 1846 r., wykazał, że dzisiaj na terenach objętych „leberyją" niewiele się robi, aby pamięć o niej nie zgasła ${ }^{1}$. Podobny proces dotknął postaci Jakuba Szeli, gdyż w historiografii zarówno polskiej,jak obcojęzycznej nie ustalono do tej pory wielu podstawowych informacji z jego życia - brak daty śmierci, dzień urodzin też nie jest zbyt pewny, nie mówiąc już o innych, trudniejszych kwestiach. Z jego biogramu opracowanego przez historyka krakowskiego Tomasza Kargola dla PSB w 2011 r., gdzie rzetelnie wykazany został tematyczny dorobek z literatury pięknej i historiografii, wynika, że więcej powstało dzieł o micie Szeli niż o nim samym² ${ }^{2}$. Czy naprawdę ten człowiek - zapisany w literaturze przez tak wiele piór, w tym najwybitniejsze Zygmunta Krasińskiego, Stanisława Wyspiańskiego, Stefana Żeromskiego czy Marii von Ebner-Eschenbach - nie zasłużył na merytoryczną biografię? Ten stan rzeczy stał się inspiracją do powstania

* W XIX w. stosowany był zapis tego imienia „Jakób”. Zmiany w pisowni dokonane w 1936 r. skutkowały wymienieniem samogłoski „ó" na „u”. Innowacje wprowadzono jednak niekonsekwentnie, gdyż nie objęły one całej grupy wyrazów („król”, ,Józef", etc). Według autora, zwłaszcza przy tak znanej postaci jak Szela, powinno się wrócić do pierwotnego zapisu jego imienia, m.in. po to, aby lepiej oddać ducha epoki. Jednakże po konsultacji z onomastą Tomaszem Karpowiczem z Uniwersytetu Warszawskiego - za którą autor bardzo dziękuje - w pracy nie zastosowano tej formuły. Powrót do pierwotnej pisowni bez uprzedniego przygotowania czytelnika jest krokiem ryzykownym, który zaburzyłby komunikację, szczególnie kiedy potraktowany byłby w sposób wybiórczy (jedynie wobec Szeli). Autorowi pozostaje więc postulowanie dokonania wspomnianych zmian w przyszłości w sposób szerszy, strukturalny, nieodnoszący się tylko do postaci legendarnego chłopa.

${ }^{1}$ A. Bartosz, Pamięć Rabacji - historia jednego pomnika, „Rocznik Tarnowski” 11, 2006, s. 56 n.

${ }^{2}$ T. Kargol, Jakub Szela, PSB, t. 47, Warszawa-Kraków 2011, s. 607-611. 
niniejszego przyczynku ${ }^{3}$, w nadziei, że doprowadzi on choć w niewielkim stopniu do „uczłowieczenia” legendarnego chłopa ${ }^{4}$.

Materiały źródłowe odnoszące się do Szeli przedstawiają się niezwykle ubogo. Składa się na nie pismo, jakie wystosował on do cesarza w lipcu 1847 r. ${ }^{5}$, , kwitów” z okresu jego „rządów” w 1846 r. oraz zeznania złożonego przez niego w momencie aresztowania w 1846 r. ${ }^{6}$ Znane są trzy życiorysy Szeli. Pierwszy znajduje się w Ossolineum ${ }^{7}$, kolejny, opatrzony datą 6 kwietnia 1846 r., odnaleziony został przez Sławomira Kalembkę w Pary$\dot{z} u^{8}$. Te podobne do siebie, napastliwie, wręcz agresywnie napisane teksty w dużej mierze pokrywają się z trzecim, znacznie obszerniejszym życiorysem, stworzonym przez Ludwikę z Boguszów Gorayskąa ${ }^{9}$ Istotnym źródłem są wspomnienia chrześniaka Szeli, Andrzeja Szydłoskiego ${ }^{10}$. Adam Bogusz w 1903 r. w swojej tendencyjnej relacji wykorzystał selektywnie wspo-

${ }^{3}$ Praca niniejsza swój kształt zawdzięcza zaangażowaniu i pomocy wielu osób, spośród których autor szczególnie podziękować pragnie swojej partnerce Ewie oraz Luzianowi Geierowi z Bukowina Institut w Augsburgu, ks. Ryszardowi Radoniowi z Siedlisk-Bogusz, Siminie Iftimiu z Arhivele Naționale ale României w Suczawie, Wacławowi Szczepanikowi z Uniwersytetu Jagiellońskiego, Cristinie Cehaniuc ze Stowarzyszenia Polaków w Kaczyce oraz Krzysztofowi Ślusarkowi z UJ. Praca powstała przy wsparciu finansowym miasta Wiedeń, udzielonym życzliwie przez wiceburmistrz Renate Brauner oraz burmistrza Michaela Häupla.

${ }^{4}$ Artykuł ten jest zapowiedzią monografii naukowej na temat Szeli, dlatego odnosi się tylko i włącznie do wybranych wątków z jego życia. Szersze tło historyczne i przedstawienie stanu badań czytelnik odnajdzie w szykowanej aktualnie przez autora do druku książce.

${ }^{5}$ M. Janik, Słowa pisane Jakuba Szeli (przedruk z tygodnika „Piast” w Krakowie, nr 57 i 58 z 16 i 23 XII 1934 oraz nr 1 i 2 z 6 i 13 I 1935), w: Jakub Szela. Pięć prac o Jakubie Szeli, oprac. C. Wycech, Warszawa 1956, s. 73-74; oraz P. Rysiewicz, Jakub Szela 17.VII.1787-1866 (przedruk maszynopisu pracy doktorskiej obronionej na UJ w 1932 r.), w: Jakub Szela. Pięć prac, s. 56-57.

${ }^{6}$ M.in. „Zeznania Jakuba Szeli” z Pokłosia polskiego historyczno-literackiego Józefa Wawela-Louisa, w: Rok 1846 w Galicji. Materiały źródłowe, red. J. Sieradzki, C. Wycech, Warszawa 1958 (dalej: S-W), s. 111-116, oraz protokoły spisywane z Szelą w związku z jego wyjazdem na Bukowinę: M. Janik, Zesłanie Jakóba Szeli na Bukowinę (przedruk z „Przeglądu Współczesnego” 49, kwiecień-czerwiec 1934), w: Jakub Szela. Pięć prac, s. 82-119.

${ }^{7}$ BO nr 6270/III, s. 117; przedruk w: S-W, s. 301.

${ }^{8}$ S. Kalembka, Nieznany życiorys Jakuba Szeli z 1846 roku, w: Ku Niepodległej. Ścieżki polskie i francuskie 1795-1918, red. M. Willaume, Lublin 2005, s. 77-81. Data powstania dokumentu nie odpowiada prawdzie, gdyż w tekście poruszane są wydarzenia późniejsze.

9 [L. Gorayska], Szela. Charakterystyka potworu tego, zestawiona przez pania Ludwike z Boguszów Gorajska, a zatem przez osobę, która mieszkając w Siedliskach znać go mogła, w: S. Dembiński, Rok 1846. Kronika dworów szlacheckich zebrana na pięćdziesięcioletnia rocznice smutnych wypadków lutego, Jasło 1896, s. 328-333.

${ }^{10}$ Relacja chłopa - uczestnika powstania 1846 r., w: S-W, s. 301-311, 321. Szydłoskiego w literaturze określa się mianem „Szydłowskiego”, co jest sprzeczne z wpisami w siedliskich księgach metrykalnych. 
mnienia dwojga innych bezpośrednich świadków krwawych zajść: proboszcza siedliskiego ks. Jana Jurczaka oraz swojej ciotki L. Gorayskiej ${ }^{11}$.

W pozyskaniu nowych źródeł uwaga skierowana została na prasę, archiwalia i księgi metrykalne. Kwerendą objęto gazety niemiecko- i polskojęzyczne, nie uwzględniając francuskich i brytyjskich, przy założeniu, że nie miały one większego wpływu na bieżące poczynania dworu wiedeńskiego (oczywiście, biorąc pod uwagę tylko Jakuba Szelę). Cezury poszukiwań wykreślił rok 1846, czyli moment, kiedy Szela stał się sławny w Europie, oraz lata 1858-1868, w jakich mógł nastąpić jego zgon ${ }^{12}$. Literatura bowiem - bez jakiegokolwiek potwierdzenia w źródłach - wskazywała na rok 1862 lub 1866. Szczególnie ważkie okazały się znaleziska w aktach policyjnych w Allgemeines Verwaltungsarchiv, oddziale Österrichisches Staatsarchiv w Wiedniu ${ }^{13}$, pomimo że zostały one zdziesiątkowane w pożarze Justizpalast w 1927 r. Archiwalia lwowskie z Gubernium i Namiestnictwa zostały przebadane przez Eugeniusza Barwińskiego, Michała Janika czy Piotra Rysiewicza, dlatego kluczowe stało się zdobycie materiałów z terenów dawnej Bukowiny, przechowywanych dzisiaj w Suczawie, Bukareszcie i Czerniowcach. Wreszcie dotarcie do ksiąg metrykalnych, przede wszystkim bukowińskich, pozwoliło ustalić wiele zależności związanych z rodziną Szelów. Księgi te, często niedochowane do naszych czasów, dostępne są jednak w formie odpisów (niejednokrotnie niekompletnych), które podczas II wojny światowej sporządzone zostały przez tzw. Einwandererzentrale (EWZ), zajmującą się kolonizacją Niemców. Zebrany w ten sposób materiał pozwolił na odkrycie kolejnych, nieznanych faktów z życia legendarnego przywódcy chłopskiego.

„Jakub Szela urodził się r. 1796 w parafii Siedliska w cyrkule tarnowskim $^{14}$ - głoszono na wstępie w życiorysach w prasie europejskiej, dzięki

11 [L. Gorayska], Podług pamiętnika W. Pani Ludwiki z Boguszów Gorajskiej, udzielonego przez syna, W. Pana Augusta Gorajskiego, marszałka powiatu krośnieńskiego, właściciela Moderówki i innych dóbr w Krośnieńskiem, w: S. Dembiński, op. cit., s. 311-325. Por. F. Prek, Czasy i ludzie, oprac. H. Barycz, Wrocław 1959. W Archiwum Adama Bogusza (dalej: ABog), nr 8, w Archiwum Narodowym w Krakowie, oddz. Wawel, znajduje się odpis wspomnień L. Gorayskiej, przy braku zapisek ks. Jurczaka.

${ }^{12}$ M.in.: „Bukowina. Landes- und Amtszeitung”, „Berlinische Nachrichten von Staats- und gelehrten Sachen”, „Wiener Zeitung”, ,Allgemeine Oderzeitung”, ,Deutsche Allgemeine Zeitung”, „Frankfurter Oberpostamts-Zeitung” (dalej: FOZ), „, Gazeta Wielkiego Xięstwa Poznańskiego” (dalej: GWXP), „Demokrata Polski”, „Przegląd Polski”, ,Dziennik Polski”, ,Dziennik Narodowy”, „Czas”, „Gazeta Lwowska”.

${ }^{13}$ Dzięki temu przekazane zostały przez autora do redakcji PSB informacje o dokumentach z Österreichisches Staatsarchiv w Wiedniu (dalej: ÖStA), oddz. Allgemeines Verwaltungsarchiv (dalej: AVA), Oberste-Polizei-Behörde, Präs. II (dalej: OPB), kart. 30 , fasc. $5720 / 1854$.

${ }^{14}$ Siedliska (-Bogusz) Dolne i Górne, wieś pod Pilznem, nad potokiem Kamienica 
którym przedstawiony został szerokiej publiczności - jest poddany ze wsi Smarzowy" ${ }^{15}$. Informacja zawierała istotny błąd, gdyż urodził się on 9 lat wcześniej we wspomnianej Smarzowej ${ }^{16}$, należącej do rodziny Boguszów ${ }^{17}$. Ochrzczony został 15 lipca 1787 r. w kościele parafialnym. Za datę jego urodzin można przyjąć 14 lipca, czyli dzień „kalendarzowego” imiennika, gdyż - jak słusznie zauważył Krzysztof Traciłowski - dopiero od ok. roku 1815 zaczęto wpisywać w księgach metrykalnych obok daty chrztu również dzień narodzin ${ }^{18}$. W literaturze niezwykle długo funkcjonował 15 listopada 1787 r., podany przez A. Bogusza ${ }^{19}$. Na marginesie mówiąc, poprawną datę urodzin Szeli pierwszy podał ks. Stefan Dembiński w 1896 r., bazując na wspomnieniach ks. Jurczaka ${ }^{20}$. Oto pełny zapis tego faktu z księgi chrztów wsi Smarzowa: „[rok] 1787, 15 Eius [tego samego], Jacobus, á Matt. Sopini c.s. [przez ks. Mateusza Sopini], Nr. domus 51, [ojciec] Joannes Szela hortulanis [zagrodnik], [matka] Anna Lukaszowna, [chrzestni] Adalbertus Jędrzeyczak i Hedvigis Białaska"21. Omyłka A. Bogusza była

(dawniej nazywanym też Jezioro), prawym dopływem Wisłoki. Parafia, należąca do diecezji tarnowskiej, obejmowała w XIX w. Smarzową, Gorzejową, Głobikową, Grudnę Dolną i Górną, Bączałkę i Kamienicę Górną, Siedliska, SGKP, t. 10, Warszawa 1889, s. 510-511. Przydomek „Bogusz” nadano w 1844 r. (K. Kawula, „Obrazki z dziejów parafii Siedliska-Bogusz", Siedliska-Bogusz 1968 (mps), s. 142).

${ }^{15} 21$ kwietnia 1846 r. w poczytnej GWXP (92, s. 372 [2]) opublikowano życiorys Szeli przesłany do redakcji z Krakowa 10 kwietnia. Informacje powtórzył FOZ (114, 25 IV 1846, s. 1127), a za nim m.in. „Deutsche Allgemeine Zeitung” (115, 25 IV 1846, s. 1068). Na początku maja podał go „Dziennik Narodowy” (265, 9 V 1846, s. 4). Bardzo zbliżona treść wszystkich biogramów, pokrywająca się ze znanymi dotychczas trzema życiorysami Szeli, skłania do stwierdzenia, że źródłem ich pochodzenia byli członkowie rodziny Boguszów, którzy przeżyli krwawą jatkę zgotowaną im 20 lutego 1846 r. przez poddanych pod przewodnictwem Szeli.

${ }^{16}$ Smarzowa, wieś pod Pilznem, par. rz.-kat. w Siedliskach-Bogusz. Leży w okolicy pagórkowatej, nad potokiem Kamienica (Jezioro), prawym dopływie Wisłoki, $7 \mathrm{~km}$ od Brzostka. Istnieje co najmniej od XV w., Smarzowa, SGKP, t. 10, s. 867; z dniem 1 stycznia 2000 r. nazwę wioski zmieniono na „Smarżowa”.

${ }^{17}$ Senior rodu Stanisław Bogusz, były szambelan na dworze Stanisława Augusta Poniatowskiego, miał żonę Apolonię i pięciu synów: Feliksa, Wiktoryna, Stanisława, Henryka i Nikodema oraz córkę Ludwikę (Gorayską). W rękach Boguszów oprócz Siedlisk-Bogusz i Smarzowej były też wsie Rzędzianowice, Żarówka i Rzemień. W 1846 r. w Smarzowej rządził Nikodem, a rok później Wiktoryn przejął Siedliska-Bogusz, biorąc do siebie ojca, A. Bogusz, Karty z dziejów wsi Smarżowy oraz Siedlisk powiatu pilzneńskiego, Kraków 1904, s. 18-27.

${ }^{18}$ K. R. Traciłowski, Jakub Szela, Puławy-Rudki 2011, s. 20.

${ }_{19}$ A. Bogusz, Wieś Siedliska-Bogusz. Monografia zebrana $z$ dokumentów i wspomnień rodzinnych ze szczególnym uwzględnieniem wypadków roku 1846 i życiorysu Jakuba Szeli, Kraków 1903, s. 21; sprostowanie, jakie wprowadził w 1932 r. Rysiewicz (op. cit., s. 30), gdzie podał poprawną datę, umknęło uwadze większości badaczy.

20 [L. Gorayska], Szela, s. 331.

${ }^{21}$ Liber baptisatorum Smarzowa (dalej: LBS) 1784-1821, t. 5, k. 7. 
prozaiczna, gdyż zapis „Eius”, przypomina tam „9bris”, jak określano listopad. Chodzi zatem o „eiusdem”, czyli „tego samego" i odnosi się do wpisanego w powyższej rubryce miesiąca ,July",lipca. Równie nieczytelny zapis w siedliskiej księdze utrudnił ustalenie nazwiska matki Szeli. Ks. Karol Kawula widział „Litak” (Litakowna) ${ }^{22}$, analiza porównawcza z innymi wpisami wskazuje jednak na „Lukaszowna”, co potwierdzają żyjący do dzisiaj w tamtych okolicach Łukasikowie, przy kompletnym braku Litaków ${ }^{23}$.

W wieku około dwudziestu, trzydziestu lat Szela rzekomo:

Rodziców bił i wyganiał ich z chałupy, aby mu ją oddali, zgrozą był dla parafii. Od komisji sprowadzonej na niego został wtedy ukarany.Zatem spaliwszy ojcu chatę, uciekł i 2 lata wałęsał się i trudnił łotrostwem. Dowiedziawszy się o śmierci rodzica wrócił do wsi i objął grunt na pół z macochą i bratem, ale żyli w zatargach, zatrudniając zwierzchność gorszącymi procesami i nareszcie w r. 1828 cyrkuł kazał mu oddać grunt macosze. Zostawszy kumornikiem ${ }^{24}$ Szela raptem zaczął się dworowi przypochlebiać, pracować koło ciesiołki, ożenił się i dostał od pana wakującą zagrodę, której pragnął. Wtedy przy świadkach przysiągł, że odtąd nie będzie od niego cnotliwszego w gminie. Lecz chytry, zawzięty, dziki i przewrotny wnet wrócił do życia dawnego. Zaprzestał odrabiać powinności, rozpoczął proces z dworem i bratem - pił, łajdaczył się i gromadę buntował. Zesłana komisja zagroziła mu, że z łaski pana odebrany grunt utraci, jeśli nie poprzestanie skarg i nie będzie chciał jak inni robocizn uiszczaćéc.

\section{Gorayska znowu:}

Zuchwalstwo jego do coraz większego stopnia dochodziło, coraz więcej ufał w łagodność zwierzchności dworskiej, coraz więcej się jej narażał, lecz wprost nic mu dowieść się nie było można, gdyż taką sobie zjednał przewagę między ludem, że nikt na niego świadczyć nie chciał, przeciwnie coraz większe były u niego zgromadzenia chłopów, którym przedstawiał, iż panowie nadużycia czynią, że nakładają daniny, że koniecznie trzeba posłać do Wiednia, aby dowiedzieć się u samego cesarza, co oni powinni oddawać dworowi, i jak odrabiać pańszczyznę. [- - ] Zwierzchność dworska zaczęła spostrzegać, iż z przyczyny Szeli są skargi, niepokoje, on sam się coraz zuchwalszym stawał, zaczęto go napominać, karać aresztem ${ }^{26}$.

${ }^{22}$ K. Kawula, op. cit., s. 44; S. Białas, Jakub Szela. Kim był, Kraków 2006, s. 10.

${ }^{23}$ Według informacji ks. R. Radonia, proboszcza parafii Siedliska-Bogusz.

${ }^{24}$ Komornik to najuboższy mieszkaniec wsi, chłop bez własnego skrawka strzechy nad głową.

${ }^{25}$ S. Kalembka, op. cit., s. 81; podobnie GWXP 92, 21 IV 1846, s. 372 [2]; FOZ 114, 25 IV 1846, s. 1127-1128; i in.

26 [L. Gorayska], Szela, s. 329. 
Kiedy zaś na pewien czas administrację Smarzowej przejął Ludwik Gorayski, potrafił on tak „utemperować” Szelę, iż tenże „przestał supliki pisać” Po trzech latach spokoju - pisała dalej córka i siostra pomordowanych Feliks Bogusz znów objął kontrolę nad wsią, ,a będąc uprzedzonym od [przez] Gorajskiego, zaczął traktować Szelę z ostrą sprawiedliwością, on też dalej był pokornym. To ujęło Feliksa Bogusza, przeniósł go na lepszą zagrodę, i dom z dworskiego drzewa wybudować dla niego kazał" ${ }^{28}$. Wydaje się, że podane informacje cechuje rzetelność - naturalnie, jeśli oddzielimy je od pomówień - mogły bowiem pochodzić od żyjących osób, czyli F. Bogusza oraz L. Gorayskiego, którzy na przemian prowadzili gospodarstwo smarzowskie. Ze względu na to, że od opisywanych wypadków minęło od kilkunastu do kilkudziesięciu lat, gdzieniegdzie mogły zakraść się nieścisłości. W 1828 r. Szela utracić więc miał prawo do gospodarstwa w wyniku rozporządzenia cyrkularnego. Możliwe, że na decyzję urzędu wpłynęły „gorszące” procesy o sukcesję, w tym spalenie chaty ojcu. Pozostając bez środków do życia, schronił się pod opiekę dziedzica, podejmując pracę jako cieśla i kołodziej, na co potwierdzenie znalazł Stefan Kieniewicz ${ }^{29}$. Szydłoski podaje więcej szczegółów: „panowie ze Smarzowej wzięli go do dworu w Grudnej Dolnej. Na Smarzowskim miał ze 14 morgów swojego [ojcowizny? - T.S.], ale on nie chciał. Graty przywieźli na to miejsce, gdzie Jantek Kurc ze Smarzowy dzisiaj (za rzeką). Stały graty miesiąc na placu zwalone, a on ani rusz, aż przystał na to miejsce przy drodze, gdzie dziś [czyli w Smarzowej - T.S.]"30.

Według Gorayskiej wszystko uległo zmianie po wybuchu powstania listopadowego, kiedy „Feliks Bogusz oddalił się do Polski, i nie wrócił aż po wzięciu Warszawy, a w czasie tej ważnej epoki, Szela także ważną rolę denuncjanta odgrywał" 31 . „W r. 1831 - pisano w innych życiorysach - rewolucja w Polsce utorowała mu nową drogę do wysokiej protekcji: donosił, śledził skwapliwie, szeroko w okolicy był znanym denuncjatorem. Później, istotnych i mniemanych emigrantów (których nazywał Polaczkami) wydawał. Odtąd skarżył każdego co mu był na przeszkodzie" ${ }^{32}$. Henryk Bogusz, najmłodszy z rodzeństwa, który przeżył jatkę podczas rabacji,

${ }^{27}$ Ibidem.

${ }^{28}$ Ibidem.

${ }^{29}$ BC, rkp. 5547, s. 876 za: S. Kieniewicz, Ruch chłopski w Galicji w 1846 roku, Wrocław 1951, s. 190; Relacja chłopa, s. 306.

${ }^{30}$ Relacja chtopa.

31 [L. Gorayska], Szela, s. 330.

32 S. Kalembka, loc. cit.; BO, nr 6270/III, s. 117; GWXP 92, 21 IV 1846, s. 372 [2]; FOZ 114, 25 IV 1846, s. 1127-1128; i in. W niektórych relacjach podano, że donosicielem był od roku 1830. 
był wcześniej prokuratorem trybunału apelacyjnego w Krakowie, uczestnicząc też w jednej z pierwszych poważniejszych konspiracji na terenie Galicji, węglarskim Związku Przyjaciół Ludu. Ten elitarny spisek przerodził się w 1835 r. w organizację spiskową obejmującą całą - jak wtenczas mawiano - „Wielką Polskę”, o nazwie Stowarzyszenie Ludu Polskiego. H. Bogusz był jej współzałożycielem ${ }^{33}$. Władze wiedziały o tym, gdyż w 1842 r. właśnie za to zwolniony został z zajmowanej posady ${ }^{34}$. Niewykluczone, że człowiek ten, mieszkający na co dzień w Krakowie, odwiedzał z innymi spiskowcami - Sewerynem Goszczyńskim, Gustawem Ehrenbergiem, Szymonem Konarskim czy braćmi Leonem i Adolfem Zaleskimi - dworki rodziców i rodzeństwa. Tuż za miedzą Siedlisk i Smarzowej, w Głobikowej, mieszkał dyrektor Ossolineum Konstanty Słotwiński, równie wielki jak on patriota polski ${ }^{35}$. Starostowie w Galicji, w dużej mierze właśnie dzięki donosom, mieli wgląd w toczące się życie polskiego świata spiskowego. Mógł więc Szela „dorabiać” sobie w ten sposób u starosty tarnowskiego Josepha Breinla von Wallerstern i niewykluczone, że właśnie dzięki temu urzędnik ów odnosił błyskotliwe sukcesy w wyłapywaniu polskich emigrantów i spiskowców ${ }^{36}$. Starosta tarnowski korzystał z „pomocy” żebraczek, kupców, jak też chłopów ${ }^{37}$.

Wspomniany rok 1831 był kluczowy dla rodziny Boguszów, gdyż wtedy „stosunki majątkowe poodmieniały się zupełnie”, a Smarzowa przeszła znowu w zarząd Nikodema Bogusza, jak pisała Gorayska. „Ten stargawszy w kampanii [powstaniu listopadowym] młode jeszcze bardzo siły, wkrótce

${ }^{33}$ S. Kieniewicz, op. cit., s. 192; idem, Konspiracje galicyjskie (1831-1845), Warszawa 1950, s. 117, 119, 124, 130; Stowarzyszenie Ludu Polskiego w Królestwie Polskim. Gustaw Ehrenberg i „świętokrzyżcy”, red. W. A. Djakow, S. Kieniewicz, W. Śliwowska, Wrocław 1978, Polskie Ruchy Społeczno-Polityczne i Życie Literackie 1832-1855; B. Łopuszański, Stowarzyszenie Ludu Polskiego (1835-1841). Geneza i dzieje, Kraków 1975, s. 162; T. Szubert, „Polnische Gefangene in der Festung Kufstein in den Jahren 1803-1853”, Wien 2007 (mps dokt.), s. 144-145; i in.

${ }^{34}$ ÖStA, AVA, Polizei-Hofstelle (dalej: PHSt), kart. 1620/15/1846, dok. 7851.

${ }^{35} \mathrm{~T}$. Szubert, „Cóż to za życie nowe, co za cuda wielkie stały się niemal dotykalnymi dla zmysłów moich!". Konstanty Słotwiński - niecodzienny więzień Kufsteinu, Sobótka 63, 2008, 1, s. $1-21$.

${ }^{36}$ Starosta przyczynił się m.in. do wykrycia komunizującego spisku Powszechnej Konfederacji Narodu Polskiego, którego członkowie trafili do twierdzy Kufstein, jednego z najważniejszych więzień politycznych monarchii, T. Szubert, „Polnische Gefangene", s.144 n.

${ }^{37}$ Archiwum Narodowe w Krakowie, oddz. Wawel, Teki Barwińskiego (dalej: TBar) 29/676/26, nr 25, k. 71, J. Breinl do prezydium Gubernium, Tarnów 9 II 1846, Zahl (Zl.) 452/ggg; ABog, nr 8, k. 69-70, J. Breinl do komisarza Ignatza Zajączkowskiego w Krakowie w sprawie ustalenia wynagrodzenia za denuncjowanie dworu szczepanowickiego, Tarnów 26 XII 1840; o opłacaniu chłopów za donosy m.in. M. Stecka, Edward Dembowski, odbitka z PH 1911, 12, 1-2, s. 31. 
gdy osiadł w Smarzowy, paraliżem został tknięty, i rządu energicznego we wsi zaprowadzić nie mógł. Szela nie czując żelaznej ręki nad sobą, znowu wichrzyć zaczął, zapomniał wszystkich dobrodziejstw dworu, [- - ] różne skargi pisywał i pańszczyznę odrabiać nie chciał, a dla domowników stawał się coraz większym tyranem” ${ }^{38}$. "W r. 1833 za zabójstwo własnej żony został skazany na 3 lata kryminału - czytamy w innym biogramie - gdy powrócił po trzech latach więzienia, był wydoskonalonym złoczyńcą. Dzięki temu i pełen pychy nie znosił żadnej zwierzchności. Nienawidził spokojnych i pracowitych chłopów - obcował z Żydami. Jednak uchodziły mu odtąd bezkarnie przestępstwa, o które był oskarżany, bo władza wyższa przychylną mu była" ${ }^{39}$. W każdym życiorysie pojawia się pomówienie Szeli o zamordowanie parobka, ale wersje różnią się od siebie istotnie. „Na koniec niepokojony zazdrością, zamordował pod kijami parobka w służbie $\mathrm{u}$ niego będącego, którego o intrygę z żoną wiele młodszą od siebie posądzał. Krewni parobka dali znać o tegoż nagłej śmierci, ksiądz go pochować nie chciał, posłano z tym raportem do cyrkułu [- - ] lecz zasługi jego w cyrkule i pieniądze od chłopów wybierane, posłużyły do jego uniewinnienia, a odtąd już zupełnie przestał odrabiać pańszczyznę, i w niczem słuchać nie chciał” ${ }^{40}$. Gdzie indziej mowa jest o dziecku: „W roku 1844 nową popełnił zbrodnię - zabójstwo na 10. letnim sierocie, którego wziął na służbę, głodząc go, bijąc, nagiego w mrozy na dworze trzymając zamkniętym. Z ran odebranych i przemrożenia umarł chłopczyna. Pleban odmówił pogrzebu, a dwór doniósł władzy. Wtedy Szela, co prędzej przekupił chirurga, przed obdukcją, i ten dał visum et repertum obojętne. Jednak za staraniem dworu i tych miejscowych świadków sąd kryminalny uznał ten czyn za zbrodniczy i kazał go odstawić do więzienia w Rzeszowie" ${ }^{41}$. W dokumencie ossolińskim z kolei przypisuje mu się zadanie gwałtu trzynastoletniej sierocie ${ }^{42}$. Do długiej listy pomówień należy dodać czyn rzekomo dokonany w młodości - zamordowanie, wespół z bratem Kazimierzem, Żyda Maślanki - dzięki czemu „obydwa doszli do dobrego bytu”. Gospodarstwo Kazimierza miało od tej pory zakwitnać, a „Jakuba Szelę znać było między chłopami idącymi do kościoła, po płaszczu sukiennym i po białej przyodziewie"43.

${ }^{38}$ [L. Gorayska], Szela, s. 330.

${ }^{39}$ S. Kalembka, loc. cit.; BO, nr 6270/III, s. 187; GWXP 92, 21 IV 1846, s. 372 [2]; FOZ 114, 25 IV 1846, s. 1127-1128; i in.

40 [L. Gorayska], Szela, s.330-331.

${ }^{41}$ S. Kalembka, loc. cit.; GWXP 92, 21 IV 1846, s. 372 [2]; FOZ 114, 25 IV 1846, s. $1127-1128$; i in.

${ }^{42}$ BO, nr 6270/III, s. 187. Wydaje się, że chodziło o przemoc fizyczną, a nie seksualną.

43 [L. Gorayska], Szela, s. 329. 
Ten strumień nienawiści płynący w kierunku Szeli był pokłosiem burzliwego finału wieloletniego sporu między gminą Smarzowa, której był przedstawicielem, a Boguszami ${ }^{44}$. Największa ilość oszczerstw pojawia się przy omówieniu okresu od 1831 do 1846 r., dokładnie wtedy, kiedy Smarzową i Siedliskami-Bogusz zarządzali zamordowani 20 lutego $1846 \mathrm{r}$. Nikodem i Wiktoryn Bogusz. Według Janika H. Bogusz w zeznaniach spisywanych w 1846 r. jawnie oskarżał Szelę o otrucie własnej żony i zabicie chłopaka ${ }^{45}$. Skąd Henryk mógł o tym wiedzieć, kiedy mieszkał, podobnie jak brat Feliks, daleko od Smarzowej? Przecież nie mógł mieć wglądu w codzienne życie wioski. Stąd zachodzi podejrzenie, że podane „fakty” to zlepek zasłyszanych przez niego plotek, echa rozmów prowadzonych kiedyś w domu ojca czy braci. Choćby błąd w dacie urodzenia Szeli albo rzekomy mord żony w 1833 r., który wtedy nie mógł mieć miejsca, gdyż cieszyła się ona dobrym zdrowiem. Tym samym też resztę pomówień należy potraktować z ogromnym dystansem. Janik wyraźnie twierdził, mając w rękach dokumenty we Lwowie, „że poświadczenie karno-sądowej registratury D 135 pokazuje, że tylko raz w r. 1833 i raz w 1844 był wprawdzie zdenuncjowany o bunt, gwałt publiczny i poranienie, jednakże z powodu braku zbrodni nie wszczęto przeciw niemu żadnego dochodzenia" ${ }^{46}$. W podobnym tonie wypowiadał się Roman Rozdolski, podkreślający zażartość sporu między upartym dziedzicem i nieodpuszczającym mu Szelą ${ }^{47}$. W sukurs idzie Oficer ${ }^{48}$ : „Należy podkreślić, że Szela już dwa razy miał do czynienia z prawem i był więziony. Jego przewinieniem za każdym razem była

${ }^{44}$ Spór ten, trwający najprawdopodobniej ok. 30 lat, jest w literaturze dość dobrze naświetlony: R. Rozdolski, Do historii „krwawego roku” 1846, KH 65, 1958, 2, s. 406-411; A. Bogusz, Wieś, s. 21, 57-58; S. Kieniewicz, Ruch, s. 190-191; Das Polen-Attentat im Jahre 1846. Aus dem Tagebuche eines Offiziers der westgalizischen Armee, Grimma 1846, s. 287; M. Sala, Geschichte des polnischen Aufstandes vom Jahre 1846. Nach authentischen Quellen dargestellt, Wien 1867, s. 281; i in.

${ }^{45}$ M.Janik, Zesłanie, s. 88.

${ }^{46}$ Ibidem.

${ }^{47}$ R. Rozdolski, op. cit., s. 408-409.

${ }^{48}$ Miano Oficera nadano w niniejszej pracy autorowi wydanej anonimowo książki Das Polen-Attentat im Jahre 1846. Aus dem Tagebuche eines Offiziers der westgalizischen Armee. Wiele wskazuje na to, że jej twórcą nie był Jakob Nitschner, jak do tej pory sądzono (m.in. M. Kłańska, Daleko od Wiednia. Galicja w oczach pisarzy niemieckojęzycznych 1772-1918, Kraków 1991, s. 58-60, 81; eadem, Problemfeld Galizien in deutschsprachiger Prosa 1846-1914, Wien 1991, s. 38, 98), ale starosta tarnowski J. Breinl. Treść i wymowa tej opowieści w wielu miejscach zbliżona jest do wspomnień, jakie zostawił on po sobie. Ich fragmenty wydali: J. Loserth, Zur vormärzlichen Polenpolitik Oesterreichs. Aus den Auszeichnungen des Tarnower Kreishauptmanns Joseph Breinl Ritters von Wallerstern, „Preußische Jahrbücher" 112, 1903, s. 249-287; B. Łoziński, Dwa upiory historyczne. Generał Benedek i starosta Breinl, „Biblioteka Warszawska” 1902, t. 246, s. 213-234, 429-458. Aktualnie przygotowywane są przez autora do druku „kompletne” wspomnienia Breinla. 
odmowa świadczeń pańszczyźnianych, kiedy wykazywał, że ma trudności w utrzymaniu się z powodu nieobecności odbywającego służbę wojskową syna" ${ }^{49}$. W innym miejscu Oficer wprost zaprzeczył stwierdzeniu H. Bogusza, że przeciwko Szeli prowadzono „wielokrotne” dochodzenia prawne, prostując na ,tylko dwukrotnie" 50 .

Niewyjaśniona dotąd była kwestia odrabiania przez Szelę pańszczyzny przed rokiem 1846. Jest to wątek, który pojawia się w relacjach świadków ${ }^{51}$, przy czym nie należy go mylić z okresem renitencji ${ }^{22} \mathrm{z}$ rabacji chłopskiej. Według Gorayskiej Szela musiał odrabiać trzy dni tygodniowo ${ }^{53}$, ale już w życiorysie paryskim czytamy: ,chłop na zagrodzie 2-dniowej” ${ }^{54}$. Wladimir v. Dulemba ${ }^{55}$, aktuariusz sądowy (tzw. Sperrakts-Kommisär) przy Szlacheckim Sądzie Krajowym pierwszej instancji w Tarnowie, który wysłany został do dominium siedliskiego, aby domknąć wszystkie kwestie prawne po zmarłych Boguszach, sporządził wiele dokumentów, w tym jeden niezwykły, opisujący wieś Smarzową z przyległościami ${ }^{56}$.Jakub Szela widnieje tam jako zagrodnik z przypisaną dwudniową, pieszą pańszczyzną oraz obowiązkiem uprzędzenia dwóch sztuk włókna, które mu powinien dostarczać dwór. Ponadto nie był obciążony innymi daninami. Szela miał też swój udział w opłatach ponoszonych przez całą gminę, które wynosiły $875 \mathrm{fl}$. $29 \mathrm{kr}$. mk., z czego aż $600 \mathrm{fl}$. gminę kosztowali urzędnicy dominikalni ${ }^{57}$. Według inwentarza najbogatsi chłopi smarzowscy, tzw. kmiecie, których było sześciu, mieli „załogę dworską”, po dwa konie i woły, pług oraz parę bron ${ }^{58}$. Szela widnieje tam na czwartym miejscu wśród zagrodników, czyli - jeśli przyjmiemy, że kolejność wpisów wynikała ze stopnia zasobności - należał do najbogatszych we wsi. Szydłoski, syn mniej zamożnego trzydniowego zagrodnika, zapewne dobrze zapamiętał, że Szela miał dwie pary wo-

49 „ist noch zu bemerken, daß Szela bereits zwei Mal gerichtliche Anstände hatte und verhaftet war. Sein Vergehen war jedes Mal entschiedene Robotstützigkeit, indem er angab, durch die Abwesenheit seines conscribirten Sohnes selbst am eigenen Lebensunterhalt gehindert zu sein", Das Polen-Attentat, s. 293.

${ }^{50}$ Ibidem, s. 280-281.

${ }^{51}$ Relacja chłopa, s. 307; A. Bogusz, Wieś, s. 25; i in.

${ }^{52}$ Renitencja - odmowa świadczenia powinności przez chłopów pańszczyźnianych.

53 [L. Gorayska], Szela, s. 330.

${ }^{54}$ S. Kalembka, op. cit., s. 80.

${ }^{55}$ Hof- und Staats-Handbuch des österreichischen Kaiserthumes, Wien 1848, cz. 1, s. 555.

${ }^{56}$ Archiwum Narodowe w Krakowie, oddz. w Spytkowicach, zesp. 29/459, Forum Nobilium Tarnoviensae (dalej: FNT), pupillaria, kart. 1655, fasc. 1852, „Inwentarz ekonomiczny dóbr Smarzowy z przyległościami Smarzowski i Łazy w Cyrkule Tarnowskim położonych do niegdyś ś.p. Nikodema Bogusza należących na gruncie tychże dóbr sporządzony jako dnia 20. listopada 1846 zaczęty" (do 12 grudnia), k. 280-283.

57 Ibidem, k. 284.

${ }^{58} \mathrm{~W}$ grudniu $1846 \mathrm{r}$. w wiosce było 97 rodzin, z czego 6 kmieci, 60 zagrodników, 4 czynszaków i 25 komorników, „Inwentarz ekonomiczny dóbr Smarzowy”, k. 280-283. 
łów, którymi oborywał ziemniaki, a jak swego czasu nie dostał za nie dobrej ceny na jarmarku, potrafił je zabić i zjeść, skórę przeznaczając na buty dla dzieci ${ }^{59}$. Nie każdego gospodarza było też stać na parobka, a takim pochwalić się mógł przecież Szela. Nie wolno też zapomnieć, że oprócz wołów u każdego bogatszego gospodarza była co najmniej jedna krowa, a nie brakowało też świń i kur.Za pomocą inwentarza Dulemby możemy przybliżyć wygląd domu Szeli. W opisie folwarku należącego do Smarzowy w Łazach czytamy: „Budynek dworski pomieszkanie polowego, z drzewa okrągłego zbudowany pod pokryciem słomianem nie najlepszem. Nic innego jak lepsza chałupa chłopska, [wyróżn. T.S.] ma sień wchodową po prawej i po lewej stronie tejże po jednej izbie mieszkalnej bez podłogi z powałą z tarcic złą, w większej dwa chłopskie okienka w mniejszej jedno, na wprost zaś z sieni wchód do małej ciemnej stajenki. Drzwi wszystkie w tym budynku są z tarcic na biegunach drewnianych z klamką albo z kołowrotkiem"

Wracając do pytania o odrabianie pańszczyzny przez Szelę, posłużymy się znów Szydłoskim: „chodziłem ze Szelą jak chrzestny ojciec na pańskie dwa dni w tygodniu. Jakem zaszedł, to mnie karbownik wrócił - nie - kazał mi dać jeść w ten dzień nic nie robić i wieczór pod cwancygiera - i tak było długo, bo oni chcieli, żeby sam Szela poszedł na pańskie, a on nie chciał. Przyjechała Komisja wypytywali mnię jak było i przepadło 30 dni" ${ }^{\prime \prime 1}$. Jeśli temu wierzyć, to dominium wolało przekupić cwancygierem „zastępcę” Szeli, aby tylko wykazać, że nie odrabia on nakazanych obowiązków. Oficjalne potwierdzenie tego faktu znajduje się w raporcie policyjnym sporządzonym na wiosnę 1846 r. dla ministra policji, że Szela przez ostatnie cztery lata „nie chodził na pańskie"62. Wzmianka ta pokrywa się z informacją Gorayskiej o rozluźnieniu dyscypliny w Smarzowej, odkąd N. Bogusz doznał paraliżu (1842 r.), a w rodzinie pojawiły się dalsze choroby, dlatego „sprawa Szeli w zapomnienie poszła"63.

Kolejne niejasności dotyczą małżeństw i liczby dzieci Szeli. Według A. Bogusza żenił się on cztery razy ${ }^{64}$, natomiast ks. Kawula wskazywał na trzy małżonki ${ }^{65}$. Odpowiedź znajduje się w księgach metrykalnych wsi Smarzowa ${ }^{66}$. Dnia 6 listopada 1809 r. dwudziestodwuletni Jakub bierze

${ }^{59}$ Relacja chłopa, s. 307.

${ }^{60}$ „Inwentarz ekonomiczny dóbr Smarzowy”, k. 275.

${ }^{61}$ Relacja chłopa, s. 306.

62 ÖStA, AVA, PHSt, kart. 1620/15/1846, dok. 7130, J. Altmann do J. Sedlnitzkiego, Podgórze 28 VI 1846, Raport Langera (akta nadpalone).

63 [L. Gorayska], Szela, s. 331.

${ }^{64}$ A. Bogusz, Wieś, s. 23-25.

${ }^{65}$ K. Kawula, op. cit., s. 44.

${ }^{66}$ Przyjęto założenie, że Szela żenił się tylko w rodzinnej miejscowości. 
ślub z młodziutką, szesnastoletnią Rozalią Chodór ${ }^{67}$. Z tego związku rodzi się sześcioro dzieci. 21 lipca 1811 r. ochrzczona zostaje Anna ${ }^{68}$. Miała brata bliźniaka, czego nie odnotowano w księdze chrztów, lecz tylko w księdze zgonów. Pod datą 26 lipca 1811 r. ksiądz wpisał tam Jana, syna Jakuba, który przeżył dokładnie siedem dni ${ }^{69}$. Jeśli więc odejmiemy je od 26, otrzymamy datę urodzin bliźniaków: 20 lipca 1811 r. Istnienie Jana zostało przeoczone przez dotychczasowych badaczy. Kolejnym dzieckiem Szeli, ochrzczonym 26 grudnia 1812 r., jest ponownie $\mathrm{Jan}^{70}$, ale nie żył on długo, umierając 23 września $1814 \mathrm{r} .{ }^{71} 11$ kwietnia $1814 \mathrm{r}$. pojawia się kolejny potomek, córka Katarzyna ${ }^{72}$, ale i ona umiera po dwunastu miesiącach ${ }^{73}$. Wreszcie w roku 1815 stan ten uległ zmianie, gdyż 3 listopada Rozalia rodzi córkę Katarzynę, która z pewnością przeżyła ${ }^{74}$. Tego samego roku, 12 grudnia, w wieku siedemdziesięciu lat umarła matka Szeli, Anna ${ }^{75}$. Miało to miejsce w domu o numerze 54, czyli w chałupie Jakuba. Półtora roku później, 1 maja 1817 r., świat ujrzał Stanisław, ostatnie dziecko z tego związku, owiany złą sławą „pułkownik” z rabacji ${ }^{76}$. Małżeństwo z Rozalią kończy się jej śmiercią 21 grudnia 1818 r., po dziewięciu latach chyba niezbyt przykładnego pożycia ${ }^{77}$. Według A. Bogusza ta była wychowanka dworska, dzięki której Szela miał zyskać kawałek gruntu, była przez niego „niemiłosiernie” bita „za wdzięczność i przywiązanie do dworu” i dlatego „wkrótce się jej pozbył" ". Wybitny działacz chłopski Jakub Bojko przyznał rację Boguszowi: „Kilku chłopów ze Smarzowy onegdaj mówili mi, że podejrzenie Szeli [o niewierności żony] było słuszne" 79 . Brak szacunku dla Rozalii potwierdzić może też nieprzestrzeganie przez Jakuba żałoby, gdyż zaledwie miesiąc po jej śmierci, 24 stycznia 1819 r., ożenił się z dziewiętnastoletnią Agnieszką Prewendoską ${ }^{80}$. Może przyczyna tak szybkiego ślubu była bardziej prozaiczna,

${ }^{67}$ Liber copulatorum Smarzowa 1784-1898, t. 2 (wg starej numeracji t. 3), (dalej: LCS), k. 21.

${ }^{68}$ LBS 1784-1821, t. 5, k. 74; K. Kawula, ibidem.

${ }^{69}$ Liber mortuorum Smarzowa 1787-1855, t. 3 (dalej: LMS), k. 32. Brak informacji o matce.

${ }^{70}$ LBS 1784-1821, t. 5, k. 78; K. Kawula, ibidem.

${ }^{71}$ LMS, k. 36.

${ }^{72}$ LBS 1784-1821, t. 5, k. 81; K. Kawula, ibidem.

${ }^{73}$ LMS, k. 37.

${ }^{74}$ LBS 1784-1821, t. 5, k. 86; K. Kawula, ibidem.

${ }^{75}$ LMS, k. 38.

${ }^{76}$ LBS 1784-1821, t. 5, k. 89; K. Kawula, ibidem.

${ }^{77}$ LMS, k. 41.

${ }^{78}$ A. Bogusz, Wieś, s. 23.

${ }^{79}$ J. Bojko, Smutne opowieści o 1846 roku, w: S-W, s. 353-355.

${ }^{80}$ LCS, k. 27. 
bo przecież miał pod strzechą co najmniej dwoje małych dzieci, o które trzeba było zadbać. Z pewnością bowiem żyli Katarzyna i Stanisław, ponieważ wzmiankowani są później wielokrotnie, a może też Anna, chociaż w księgach smarzowskich nie ma po niej śladu. Według A. Bogusza ojciec nowej żony Jakuba, Wojciech Prewendoski, zagrodnik tak jak i Szela, był wielkim zwolennikiem zięcia w walce $\mathrm{z}$ dworem, co zapewne skłoniło go do oddania mu ręki córki. Księgi smarzowskie milczą o ewentualnych dzieciach z tego związku. A. Bogusz twierdził, że „nie żyła długo”, a „Szela mając opinię tyrana na żony, nie mógł znaleźć odpowiedniej kandydatki we wsi rodzinnej i ożenił się po raz trzeci z jakąś dziewczyną z obcej wsi, którą tak bił i katował, że od niego uciekła i wkrótce umarła"81. Pojawienie się tej nieznanej „trzeciej” kobiety budzi zastrzeżenia. Jej istnienia nie potwierdzają księgi metrykalne, a nie wydaje się, aby Szela żył w związku pozamałżeńskim, bo jak pokazały wypadki 1846 r., Kościół - traktowany przezeń instrumentalnie - był ważnym elementem jego świata. Nie można jednak z całą pewnością tego wykluczyć, gdyż zaślubiny mogły odbyć się poza Smarzową. Bardziej prawdopodobne wydaje się jednak, że to Agnieszka uciekła od swojego męża i zmarła z dala od niego. Sędziwy Szydłoski nie daje też odpowiedzi na to pytanie, pamiętając tylko dwie małżonki Szeli ${ }^{82}$. Ostatnią wybranką blisko czterdziestoczteroletniego chłopa była, równie młoda co pozostałe żony, siedemnastoletnia Salomea Niewiarowska. Ślub wzięli 9 lutego $1831 \mathrm{r}$. w rodzinnej parafii ${ }^{83}$.

Przyszła po prośbie błagalna babka z Małej Niewiaroszczanka do Szeli wspominał Szydłoski - On się jej skarży, że go żadna dziewka nie chce, a ona mówi, że ma córeczkę. Szela mówi dobrze. Dajże jej Kaśka (córka Szeli z I-go małżeństwa) słoniny na wieczerzę i jak się przenocuje, to pójdzie do domu i na drugi dzień na wieczór przyszła i przyprowadziła ładną córeczkę (była nieślubna), a matka mówiła wtedy, że ją już raz cygany porwały, jak pasła gęsi przy potoku, ale ją wnet odebrali. Obie poczęstował Szela wódką z miodem, kazał dać wieczerzę i zaraz jutro przebrał ją w chusty i poszedł na zapowiedzi. Zapowiedzi wyszły, ks. proboszcz ślubu nie chciał dać. Tak co ten Szela robi? Kazał konie zaprzęgnąć, bierze ze sobą dziewczynę Salusię i czworo ludzi, jedzie do Biskupa do Tarnowa. X. proboszcz z tego miejsca jak Nowak za Lubasiową przez Bartka Żmudę wrócił go i dał ślub. [- - ] Było to przed rabacją, bo chłopiec Józek syn [Szeli] już miał około 6 lat na rabacji ${ }^{84}$.

\footnotetext{
${ }^{81}$ A. Bogusz, Wieś, s. 24.

${ }^{82}$ Relacja chtopa, s. 305.

${ }^{83}$ LCS, k. 37.

${ }^{84}$ Relacja chtopa, s. 305-306.
} 
Tutaj najlepiej widać, jak zawodziła Szydłoskiego pamięć - Józef podczas rabacji miał ukończone dokładnie 14 lat, gdyż urodził się 24 lutego $1832 \mathrm{r}^{85}$ Dotychczasowi badacze przeoczyli moment jego narodzin. Jak wiele na to wskazuje - był on jedynym potomkiem z ostatniego znanego nam związku Szeli, pomimo że w różnych przekazach z 1848 r. pojawia się „małoletnia" córka Katarzyna. Będzie o niej mowa przy okazji wyjazdu Szeli na Bukowinę.

Od 1822 r. Szela, jako deputowany gminy Smarzowej, zaangażowany był w spór z rodziną Boguszów. Według Sali, polskojęzycznego urzędnika, który większość swojego życia spędził w Galicji, deputowani tacy wyróżniali się z ogółu chłopstwa jedynie sprytem, będąc w zasadzie ciemnymi prostaczkami („roh und unwissend”) ${ }^{86}$. Uważał, że Szela nie odbiegał od tego schematu. Do dzisiaj nie udało się badaczom ustalić, czy osławiony chłop umiał czytać i pisać. Jego niepiśmienność podnosiły wzmiankowane życiorysy, ksiądz siedliski Jurczak ${ }^{87}$, A. Bogusz ${ }^{88}$ czy Sala $^{89}$. Ludzi z kolei twierdzących przeciwnie też było sporo, choć najczęściej ich wiedza na ten temat pochodziła $\mathrm{z}$ drugiej ręki ${ }^{90}$. Odpowiedzi należy szukać więc w dokumentach $\mathrm{z}$ epoki. W księgach metrykalnych Smarzowej Jakub pojawia się wielokrotnie. 16 lutego 1825 r. jest świadkiem na ślubie Wojciecha Jędrzeyczaka i Agnieszki Niewiarowskiej, gdzie podpisuje się krzyży$\mathrm{kiem}^{91}$. W 1833 r. na ślubie Mateusza Szydłoskiego i Zofii Szeli też jako świadek stawia trzy krzyżyki ${ }^{92}$. W 1834 r. na zaślubinach Józefa Mirusa i Małgorzaty Pasek widnieje jeden krzyżyk ${ }^{93}$. Gorayska podawała, że przed rabacją Szela "dyktował pisarzowi Winiarskiemu" ${ }^{4}$, natomiast podczas pierwszych dni rozruchów wzięta do jego chałupy seniorka rodu Boguszów Apolonia ,zastępowała miejsce pisarza Szeli" ${ }^{95}$, co wykazano też we wszystkich życiorysach prasowych. Ustalenia piśmienności Jakuba podjął się Janik ${ }^{96}$. Analizę oparł na czterech dokumentach, z czego najważniejszym była petycja z 1 kwietnia 1846 r. podpisana przez stu chłopów, gdzie przy nazwisku Szeli widniały trzy krzyżyki, a na końcu, jako że parafował

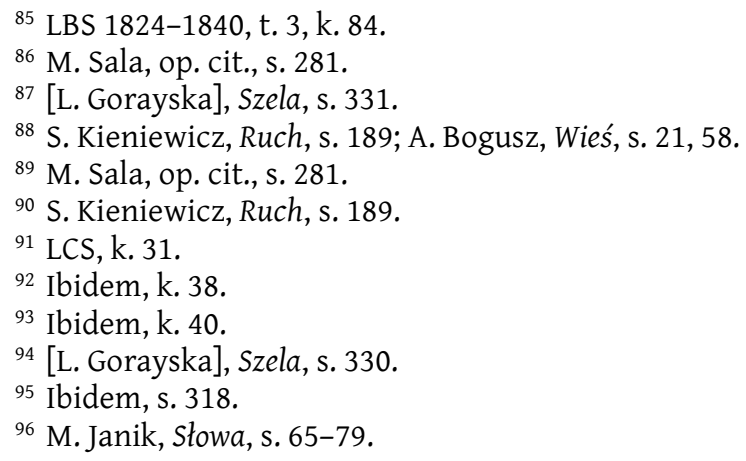


cały dokument, figurował jego czytelny autograf. Upoważniło to Janika do obdarzenia siedliskiego chłopa tą umiejętnością. Na poparcie wskazał też inne dokumenty wychodzące z kancelarii rabantów, które jednak pisane były - jak wykazał Czesław Wycech - przez przymusowo zatrudnionych „pisarzy”, Nikodema Kruczkiewicza i Bogdana Wiśniowskiego ${ }^{97}$. Należy dodać, że najprawdopodobniej większość z tych „kwitów” nie tylko podpisał, ale napisał w imieniu Jakuba, radzący sobie nieźle z piórem jego syn Józef - charakter pisma, jakim zostały napisane, zbieżny jest $\mathrm{z}$ dokumentami Szeli wytworzonymi przez niego na Bukowinie ${ }^{98}$. W piśmie sporządzonym we Lwowie 14 grudnia $1847 \mathrm{r} .{ }^{99}$, będącym porozumieniem zawartym między Szelą a starostą bukowińskim o warunkach jego przesiedlenia, chłop podpisuje się „standardowo” krzyżykiem, a urzędnik starostwa, sekretarz gubernialny Phillip Wohlfahrth, dopisał obok: ,Jacob Szela dessen Namensgefertigte Wohlfahrth”, czyli „podpisujący się za Jakuba Szelę Wohlfahrth" ${ }^{100}$. Te słowa obalają mit o umiejętnościach Szeli. W celu uzyskania całkowitej pewności analfabetyzmu przywódcy chłopskiego spójrzmy na jeszcze jedno pismo nazwane „Publications-Protokoll”, sporządzone w Sołce na Bukowinie 20 grudnia 1851 r. „Gdy Jakob Schella stawił się po otrzymaniu wezwania do tutejszego urzędu, w obecności dwóch świadków wysokie rozporządzenie zostało mu przetłumaczone na znany mu język polski, dokładnie przeczytane słowo po słowie [- - ] [Co on] potwierdził własnoręcznym podpisem «X»". Na krzyżyku jest odcisk palca, być może Szeli. Obok, tym samym charakterem pisma, jakim sporządzono dokument, napisano - podobnie jak w Tarnowie „Namensfertiger Jakob Szela Paul Koczmay” ${ }^{101}$. W świetle kompletnej niepiśmienności smarzowskiego chłopa jakże szyderczo brzmi wypowiedź szefa policji lwowskiej Leopolda Sacher-Masocha, która dla wielu badaczy przez blisko 170 lat służyła za świadectwo uzdolnień chłopskiego przywódcy: ,od wczesnych lat zwracał na siebie uwagę inteligencją, ucząc się

${ }_{97}$ S-W, s. 113 i 117; M. Sala, op. cit., s. 277; C. Wycech, Powstanie chłopskie w roku 1846. Jakub Szela, Warszawa 1955, 149.

${ }_{98}$ FNT, successionaria, kart. 926, fasc. 5499, k. 147-219. Tutaj znajduje się większość dokumentów, które wyszły z „kancelarii” Szeli.

99 ÖStA, AVA, PHSt, fasc. 1509/1848 „Jakob Szela”, Ostateczny protokół o warunkach przesiedlenia J. Szeli na Bukowinę, 14 XII 1847.

100 Ibidem, k. 13, s. 2.

101 „Nachdem Jakob Schella auf die von hierorts eingegangenen Vorladung erschien, so wurde derselben in Beisein zweier Zeugen der hohe Erlaß in der von ihm verstandenen pohlnischen Sprache verdolmetscht, von Wort zu Wort deutlich vorgelesen, eingehändigt und gleichzeitig angewiesen dasselbe zu bestättigen. [- - ] [was er] bestättige mit meiner eigenhändigen Unterchrift «X». Solka am 20t. Xb. 851", Дepжавний архів Чернівецької області, zespół k.k. Bukowiner Kreisamt 1786-1853 (dalej: ДАЧО), kart. 1, fasc. 10567/1851, k. 7, s.1. 
szybko czytać i pisać nie tylko języka polskiego, ale także niemieckiego, co wśród polskich i rusińskich chłopów w Galicji jest spotykane niezwykle rzadko" ${ }^{102}$.

Nie jest wykluczone, że jedną z sił sprawczych (inicjatorem) powstania roku 1846 była Rosja, od 1833 r. coraz intensywniej infiltrująca żywioł Wielkiej Emigracji ${ }^{103}$. W tym duchu już w 1847 r. pisał jeden z czołowych myślicieli emigracyjnych Bogusław Ferdynand Trentowski: „Demagogi paryskie i poznańskie, do których przyłączyli się wysłańce Paszkiewicza, a którzy, pomimo tego, iż Rząd [austriacki] miał czujne oko na patryotów i potrafił każdego z nich wypatrzyć, ażeby go oddał do więzienia lub pod nóż chłopski, nie byli wcale od władz widziani i krzątać się mogli swobodnie"104. Podobnie wpasowują się w tę tezę twierdzenia Marcelego Szaroty z 1910 r. ${ }^{105}$

W wyniku kolejnej plotki o nadchodzącej rzezi chłopów przez panów, która na wiele dni przed wybuchem powstania zawładnęła umysłami włościan, napięcie między Boguszami a ich poddanymi było tak wielkie, że 20 lutego 1846 r. chłopi z Szelą na czele wymordowali 23 osoby, w tym aż pięcioro z rodziny dziedziców ${ }^{106}$. Za wystąpieniami chłopskimi stał staro-

102 [L. Sacher-Masoch], Die polnischen Revolutionen. Erinnerungen aus Galizien, Prag 1863 , s. $108-109$.

${ }^{103}$ Rozwinięcie tej myśli przeprowadzone zostało w oddanej do druku książce autora o Szeli. Powstanie polskich demokratów roku 1846 nie doczekało się jeszcze swojego biografa. Ostatnio pisał o nim Sławomir Wegrzynowicz („Dziesięciolecie nadziei i obaw. Społeczeństwo Królestwa Polskiego wobec mikołajowskiej polityki Rosji w latach 1846-1856", Wrocław 2010, mps dokt.), wykorzystując szeroko archiwalia rosyjskie.

104 [B.F. Trentowski], Wizerunki duszy narodowej s końca ostatniego szesnastolecia. Przez Ojczyźniaka. Wyciag z „Przeglądu Politycznego Teraźniejszość i Przyszłość”, Paryż 1847, s. 95. Postać Trentowskiego najszerzej przedstawił Andrzej Walicki (m.in. B.F. Trentowski, Chowanna, czyli system pedagogiki narodowej jako umiejętności wychowania, nauki $i$ oświaty, słowem wykształcenia naszej młodzieży, red. A. Walicki, Wrocław-WarszawaKraków 1970, t. 1).

${ }^{105}$ Według Szaroty (Die letzten Tage der Republik Krakau, Breslau 1911, s. 107 i in.) głównym celem cara miało być zlikwidowanie niezależności Wolnego Miasta Krakowa, stąd świadome dopuszczenie do wybuchu powstania w mieście (i Galicji) było wystarczającym pretekstem. Rabacja zaś - z płaceniem chłopom za „głowę" powstań$\mathrm{ca}$ - stała się wypadkową tego zamierzenia. Z pierwszą tezą zgodził się S. Kieniewicz (Ruch, s. 122), ale wzbudziła ona wątpliwości u Jana Rydla (Die k.k. Armee in Galizien am Vorabend des Aufstandes im Jahre 1846, „Zeszyty Naukowe Uniwersytetu Jagiellońskiego", Prace Historyczne 121, Studia Austro-Polonica 5: Österreich-Polen. 1000 Jahre Beziehungen, 1996, s. 166; idem, C.k. wojsko austriackie w Galicji w przeddzień powstania 1846 roku, „Rocznik Bocheński” 4, 1996, s. 55). Książka Szaroty to pokłosie obronionego przez niego w 1910 r. w Bernie doktoratu. W archiwum domowym rodziny Szarotów nie zachowały się notatki dotyczące tych kwestii. Za udzielone informacje autor dziękuje wnukowi Marcelego, Tomaszowi.

106 [L. Gorayska], Podług, s. 312 n.; S. Kieniewicz, Ruch, s. 184 n.; S-W, s. 299-322; C. Wycech, op. cit., s. 133 n.; i in. Mordy na rodzinie Boguszów przeżyła m.in. Apolonia, Feliks, Henryk, Ludwika i żony Stanisława juniora i Nikodema. 
sta tarnowski Breinl, który znając doskonale nastroje wsi, umiał je wykorzystać. Zarządzając dużym terenem, wobec niespójnej polityki Lwowa, posiadał dużą swobodę postępowania, a zdając sobie doskonale sprawę z zagrożenia ze strony szlachty, zrealizował zamysł, aby jej powstanie stłumić rękami chłopów nieutożsamiających się z polskimi dążeniami niepodległościowymi (z nielicznymi wyjątkami) ${ }^{107}$. Chłopi w świetle prawa upoważnieni zostali do pacyfikacji potencjalnych wystąpień „spiskujących” panów-Polaków przeciwko cesarzowi.

Mordy na swojej rodzinie opisał H. Bogusz w prośbie wystosowanej do cesarza. Zaapelował o powołanie niezależnej komisji mającej ukarać winowajców, głównie Szeli, i ustalenie wysokości poniesionych strat w celu ich rekompensaty. Po perturbacjach petycja pojawiła się w prasie, najpierw w półoficjalnej, poczytnej i miarodajnej gazecie berlińskiej, nazywanej potocznie „Haude- und Spenersche Zeitung” ${ }^{108}$. W Wiedniu zrobiła ona tak wielkie wrażenie na odizolowanym i chorym monarsze, iż nakazał podjęcie śledztwa ${ }^{109}$. Było ich kilka, zarówno jawnych, jak i tajnych. Do dominium siedliskiego, oprócz wspomnianego komisarza sądowego Dulemby, przyjechali nowo mianowani urzędnicy cyrkularni w Pilznie: Georg Doerfl oraz komisarz Langer, którzy napisali obszerne raporty ${ }^{110}$. Minister policji hr. Joseph Sedlnitzky v. Cholitz otrzymał wizję wydarzeń od podkomisarza Johanna Baßlera ${ }^{111}$ oraz

${ }^{107} \mathrm{~W}$ fachowej literaturze utrwaliło się twierdzenie, że przygotowanie rabacji było dziełem starosty Breinla (S. Kieniewicz, Ruch, s. 132-139) oraz - ewentualnie Metternicha, o co żywioł polski natychmiast oskarżył dwór wiedeński. Sprawa ta, podobnie do kwestii kulis powstania, wymaga jednak głębszych badań - jej analiza dokonana zostanie przy publikacji kompletnych wspomnień Breinla.

108 Skarga H. Bogusza do cesarza, „Berlinische Nachrichten von Staats- und gelehrten Sachen" 105, 7 V 1846, s. 3-4. W biogramie Szeli w PSB wskazano omyłkowo, że prośba ta wydrukowana została 15 kwietnia 1846 r. „m.in. w «Demokracie Polskim», t. 6, 1846/7, nr 267”. Faktycznie pojawiła się ona w „Dzienniku Narodowym” (t. 6, 1846/1847, 267, 23 V 1846, s. 1071-1072), który jako źródło pochodzenia wskazał cytowaną gazetę berlińską. Ogłoszenie jej we Francji nie miało większego wpływu na decyzje dworu wiedeńskiego.

109 ÖStA, AVA, PHSt, kart. 1620/1846, dok. 5584, Odręczne pismo cesarza Ferdynanda, 25 V 1846; S. Kieniewicz, Ruch, s. 316-317.

${ }^{110}$ Georg Doerfl (Dörfl), od marca 1846 r. prowizoryczny burmistrz Pilzna, a w 1847 r. komisarz cyrkularny w Tarnowie, Hof- und Staats-Handbuch des österreichischen Kaiserthumes, Wien 1847, cz. 1, s. 393. ÖStA, AVA, PHSt, kart. 1620/15/1846, fasc. 6644, J. Breinl do arcks. Ferdynanda, 13 VI 1846, Odpis raportu Doerfla z 13 VI 1846; ÖStA, AVA, PHSt, kart. 1620/15/1846, dok. 7130, Raport komisarza cyrkularnego Langera.

${ }^{111}$ Johann Baßler, prov. Polizei-Untercommissär w Tarnowie, Hof- und Staats-Handbuch des österreichischen Kaiserthumes, Wien 1846, cz. 1, s. 573; ÖStA, AVA, PHSt, kart. 1620/15/1846, fasc. 7850, dok. 6735, Raport Baßlera (bardzo spalony). 
komisarza Johanna Altmanna z Podgórza ${ }^{112}$. Kolejnej relacji mandatariusza Spielmanna, którego do Siedlisk przysłał Breinl, nie udało się dotychczas odnaleźć, choć była przez urzędników wielokrotnie cytowana. Efekt konfrontacji urzędników z chłopami i pozostałymi przy życiu Boguszami oddają słowa Doerflera: „Tak wielkie oskarżenia o udział [Szeli] w mordach nie dadzą się utrzymać"113. 19 lipca 1846 r. Ferdynand I podjął więc decyzję o jej... niepodejmowaniu, czyli przekazał sprawę w ręce zarządcy Galicji,co oznaczało wygaszenie sprawy ${ }^{114}$. Widząc, co się dzieje, Boguszowie napisali w lecie 1846 r. kolejne skargi: Henryk do cesarza ${ }^{115}$, a Ludwika do Sądu Apelacyjnego w Rzeszowie ${ }^{116}$. Na to przyjechał z Rzeszowa radca kryminalny Wenzel Ržizek ${ }^{117}$, który nie ustalił nic nowego ${ }^{118}$, a wszystko dlatego, że Szela nie został zakwalifikowany do postępowania kryminalnego ${ }^{119}$. Niepoddający się H. Bogusz 20 grudnia 1846 r. wystosował do cesarza - poprzez c.k. Sąd Najwyższy (Oberste Justiz-Hofstelle) — ostatnie już zażalenie ${ }^{120}$, na które jednak nikt nie zareagował. Sprawa musiała ostatecznie trafić do lwowskiego Kryminalnego Sądu Apelacyjnego i oczywiście Sądu Najwyższego. Janik i Rysiewicz widzieli we Lwowie decyzję z 27 lutego 1847 r. z lwowskiego sądu o ukończeniu śledztwa, w którym znalazło się stwierdzenie, że Szela jest niewinny ${ }^{121}$. Sprawa załatwiona została „po cichu”, żeby jakiekolwiek echa nie dotarły do cesarza. Szela był wtedy potrzebny monarchii.

Wacław Zaleski, referent ds. galicyjskich w Zjednoczonej Kancelarii Dworskiej, w połowie marca 1846 r. pisał: „Wszystko zależy od tego, co się

112 Polizei-Oberkommisär Johann Altmann (z Podgórza), Hof- und Staats-Handbuch des österreichischen Kaiserthumes, Wien 1846, cz. 1, s. 572. Jego wersja wydarzeń przyp. 62.

113 „So groß auch Verschulden der bei dem Morden betheiligten ist, so läßt sich jedoch nicht in Abrede stellen", ÖStA, AVA, PHSt, kart. 1620/15/1846, fasc. 6644, k. 4, s. 1, Odpis raportu Doerfla z 13 VI 1846.

114 ÖStA, AVA, PHSt, kart. 1620/15/1846, fasc. 7850, J. Sedlnitzky do cesarza Ferdynanda, 1 VII 1846, Odręczne pismo monarchy.

115 BO, nr 1868/III, A. Tessarczyk, „Rzeź galicyjska w roku 1846, tudzież Powstanie Krakowskie równocześnie wybuchłe, według źródeł autentycznych opisane przez [- ], wydawcę Historyi Rzeczypospolitej Krakowskiej i innych pism", H. Bogusz do cesarza Ferdynanda, 2 VII 1846, k. 157-158.

${ }^{116}$ Apelacja Ludwiki Gorayskiej z Boguszów do c.k. Sądu Apelacyjnego w Rzeszowie, 6 VIII 1846, ibidem.

117 Wenzel Ržizek, radca w k.k. Kriminalgericht w Rzeszowie, Hof- und Staats-Handbuch des österreichischen Kaiserthumes, Wien 1848, cz. 1, s. 555.

118 TBar, nr 29, Krieg do J. Breinla 9 VI 1946, Zl. 3854/ggg, k. 131.

119 M. Sala, op. cit., s.313.

${ }^{120}$ BO, nr 1814/III, A. Tessarczyk, ,Rzeź galicyjska 1846 roku przez [- - ], wydawcę Historyi Rzeczypospolitej Krakowskiej i innych pism. Materiały", H. Bogusz do cesarza Ferdynanda, 20 XII 1846, k. 199-206.

${ }^{121}$ P. Rysiewicz, op. cit., s. 56; M. Janik, Zesłanie, s. 112-113. 
stanie w obwodzie tarnowskim. Wszystkie bowiem gminy sąsiednich obwodów patrzą na gminy obw. tarnowskiego jako na swój wzór"122. Powszechnie wiadome było, że oporem kieruje tam Szela. Pierwotnie oprócz swojej parafii nie miał on najmniejszego wpływu na przebieg wydarzeń. Już jednak na początku kwietnia, jak sam twierdził, mógł skrzyknąć jednorazowo nawet do dwóch tysięcy ludzi ${ }^{123}$. Pod jego „opiekę” zaczęli bowiem zgłaszać się coraz liczniej chłopi z pobliskich wiosek. Na początku marca było ich ok. 15, 1 kwietnia już $50^{124}$, a ostatecznie Breinl - być może z zamierzoną przesadą - określał liczbę gmin podległych Szeli na ponad $100^{125}$. Po radę przybywali do niego nawet chłopi z cyrkułów sądeckiego i sanockiego ${ }^{126}$, położonych daleko od Smarzowej. Chłopi czekali na podział gruntów i zniesienie pańszczyzny, której zresztą nie odrabiali.

Kanclerz Klemens Metternich jeszcze pod koniec marca uważał, że Szela nie stanowi większego zagrożenia ${ }^{127}$. Sytuacja uległa zmianie w początkach kwietnia, kiedy w Wiedniu zapadła decyzja o rozprawieniu się $\mathrm{z}$ rabacją siłowo. W poniedziałek wielkanocny 13 kwietnia cesarz podpisał patent, w którym pozostawiono pańszczyznę w mocy, nawołując chłopów do odrabiania powinności ${ }^{128}$. Natychmiastowe usunięcie Szeli z widowni stało się koniecznością, gdyż na nim mógł oprzeć się ewentualny opór włościan. Rosnący w siłę przywódca chłopski najpewniej nie zdawał sobie wtedy sprawy, że stał się tak istotnym graczem. W dniu podpisania cesarskiego patentu, w leżącym nieopodal Smarzowej Brzostku doszło do incydentu, który spowodował, że Szelę wezwano do Tarnowa na przesłuchanie. W jego rezultacie umieszczony został on w koszarach policji, aby jak pisał Breinl do przełożonych - „nie mógł rozmawiać z nikim bez nadzoru i był we wszystkim obserwowany, nareszcie, aby mu nie wolno było wychodzić bez upodobania". Wszystko po to - dowodził dalej starosta „ażeby położyć kres wszystkim gadaniom i oddziaływaniu tajemnie na gminy szukające u niego posady, jako też zbadać, czy naprawdę nie wywierał wpływu, jak to przyrzekł najuroczyściej, o czym jednak dotąd nie mogłem się przekonać, i ażeby w ten sposób uczynić go nieszkodliwym

${ }^{122}$ K. Ostaszewski-Barański, Wacław Michał Zaleski (1799-1849). Zarys biograficzny, Lwów 1912, s. 104.

${ }^{123}$ R. Rozdolski, rec.: Michał Janik, Zesłanie Jakóba Szeli na Bukowinę, Kraków 1934, RDSG, 4, 1935, s. 446.

124 S. Kieniewicz, Ruch, s. 192 n.; C. Wycech, op. cit., s. 150 n. i in.

${ }^{125}$ J. Loserth, op. cit., s. 286.

126 W. Michna, Pamiętniki naocznego świadka z roku 1846, „Kalendarz Ilustrowany Wieńca i Pszczółki na r. 1880".

127 S. Kieniewicz, Ruch, s. 311-313.

128 „Gazeta Lwowska” 46, 21 IV 1846. 
na kilka tygodni" ${ }^{\prime 29}$. Breinl wskazywał na jeszcze jeden czynnik tego internowania: ,Jednakże we wpływie Szeli spostrzegłem pewne zaostrzenie, gdyż obowiązek pańszczyźniany zdawał się on jedynie w ten sposób tłumaczyć, że poddani na razie tylko mają uprawiać łany dworskie, a potem miarę i kres oznaczą decyzje co do zmian przezeń oczekiwanych"130. O ile nie ulega dyskusji, iż z inicjatywy starosty przywódca chłopski znalazł się w Tarnowie, o tyle taka, a nie inna forma jego „aresztu” musiała zadowolić każdego z nich, czyli najprawdopodobniej zawarli układ. Breinl niewątpliwie zdawał sobie sprawę, że w momencie ewentualnego konfliktu pomiędzy stojącym na czele coraz większej liczby gmin Szelą a wojskiem, zeznania wodza chłopskiego obciążą go w sposób nieodwracalny. Bardziej skomplikowana jest odpowiedź na to, jakie korzyści wyniósł Szela z takiego stanu rzeczy. Pod koniec kwietnia 1846 r. starosta miał powiedzieć wiceprezydentowi Gubernium hr. Leopoldowi Lažanskiemu von Bukowa, że przyczynami internowania Szeli był wspomniany wyżej brak zaufania do niego oraz dodatkowo pogróżki okolicznych gmin wobec przywódcy chłopskiego ${ }^{131}$. Kieniewicz doszukiwał się tutaj nieszczerości Breinla, powątpiewając też w groźby chłopskie. Wydaje się jednak, że miały one bardzo duży wpływ na postawę Szeli. Należy bowiem spojrzeć na niego dwojako, jako wodza chłopskiego i człowieka. Szeli-przywódcy musiało towarzyszyć poczucie porażki i rozczarowanie z braku nadziałów gruntów pańskich oraz pozostawienia pańszczyzny. Wyartykułował to w momencie ogłoszenia patentu cesarskiego proboszczowi siedliskiemu: „A to mnie starosta oszukał, bo mnie zapewniał, że więcej już pańszczyzny nie będzie, ale kiej kazano, to trzeba - befel, jest befel"132. Jednak nie chciał wtedy jeszcze zrezygnować z dążeń chłopów, bo przecież Breinl nie napisałby pod koniec raportu o internowaniu: „O ile mogłem zauważyć, nosi się on z myślą, ażeby prosić cesarza o zmianę odnośnie do posług pańszczyźnianych" ${ }^{133}$. Był to jednak ostatni akord wodzostwa Szeli, obiecał on bowiem Breinlowi uroczyście, że użyje swojego wpływu na chłopów i przekona ich, aby zachowali spokój i powrócili do wykonywania czynności poddańczych. Gmina Smarzowa była też pierwszą, która zaczęła odrabiać pańszczyznę ${ }^{134}$. Szeli-człowiekowi z kolei nasuwać się mogły

129 ÖStA, AVA, PHSt, kart. 1620/15/1846, dok. 4571, J. Breinl do Gubernium, 20 IV 1846; M. Janik, Zesłanie, s. 110-111.

130 B. Łoziński, op. cit., s. 444.

${ }^{131}$ L. Lažanský do Gubernium, 24 IV 1946, za S. Kieniewicz, Ruch, s. 314.

${ }^{132}$ A. Bogusz, Wieś, s. 39 (befel, tj. Befehl - rozkaz).

${ }^{133}$ M. Janik, Zesłanie, s. 111. Miał zapewne na myśli petycję 50 gmin do Gubernium, którą Szela sygnował 1 kwietnia $1846 \mathrm{r}$.

${ }^{134}$ J. Loserth, op. cit., s. 285; B. Łoziński, op. cit., s. 444; FNT, successionaria, kart. 926, fasc. 5497, H. Bogusz do L. Kłosińskiego, 25 III 1846, k. 40. 
złowrogie refleksje, że chłopi pomimo lojalności nie tylko nie zostaną nagrodzeni, ale spotka ich kara za renitencję i mordy, a jego w szczególności. Mógł wpaść w panikę, że starosta nie będzie go w stanie ochronić przed zemstą chłopów, których - nie da się ukryć - zdradził. Nieobce były mu też zapewne myśli o potencjalnych mścicielach ze strony pozostałych przy życiu członków rodzin wymordowanej szlachty, szczególnie Boguszów. Co prawda w kwietniu 1846 r. niebezpieczeństwo nie było jeszcze wielkie, co uległo zmianie kilka miesięcy później, kiedy to właśnie z tej strony zaczęły płynąć złowrogie sygnały ${ }^{135}$. W momencie aresztowania realnym zagrożeniem dla Szeli byli przede wszystkim zdradzeni przez niego chłopi, zostawieni swojemu losowi dosłownie z godziny na godzinę. Echo tych lęków słychać u niego po latach: „wrogo nastawieni zaczęli dybać na moje życie" ${ }^{\prime 136}$. Lažanský 24 kwietnia pisał do arcyksięcia Ferdynanda, że Szela jest zagrożony przez chłopów z gmin przylegających do Smarzowej i należy tam wysłać komisarza kryminalnego ${ }^{137}$. W tym też duchu wypowiadał się w 1848 r. Antoni Tessarczyk: „Zagrożony jednak od własnych współwinnych ze wsi, z której on jest, iż ich zdradził, uwiódł do złego, i do nieszczęścia jakie ich czeka, po stracie dobrych panów, schronił się z własnej woli, dla własnego bezpieczeństwa do Tarnowa” ${ }^{138}$. Redaktor „Przeglądu Rzeczy Polskich” w 1860 r. również wyeksponował ten element: „[chłopi] uważali Szelę jako zdrajcę, widząc się poddanymi dworów tak samo jak dawniej, sądzili że dla osobistych widoków poruszył ich do tych okrutnych zbrodni, a potem haniebnie porzucił, wydając surowości rządu i zemście panów"139. Groźby chłopskie wobec Szeli należy więc uznać za jedną z głównych przyczyn wyrażenia przez niego zgody na odosobnienie w Tarnowie. Był to też zarazem jeden $\mathrm{z}$ istotniejszych motywów jego wyjazdu na Bukowinę.

Abstrahując od powyższych dywagacji, nie ulega też wątpliwości, że takie „otwarte” internowanie Szeli miało swój wymiar socjopolityczny i niewątpliwie było mistrzowskim posunięciem. W 1847 r. Sacher-Masoch pisał do ministra policji: „Szela przybywał w koszarach w Tarnowie ze względu na opinię publiczną" ${ }^{140}$. Niemal wolny dostęp do osławionego chłopa musiał powodować rozładowywanie narosłych emocji.

135 „Ściągnął na siebie najpłomienniejszą nienawiść szlachty”, pisał następca Breinla w marcu 1847 r., M. Janik, Zesłanie, s. 112.

136 „übel gesinnten nach meinem Leben”, ÖStA, AVA, OPB, kart. 30, fasc. 5720/1854 „Jakob Szela", k. 1, s. 1.

137 TBar 29/674/28, L. Lažanský do arcks. Ferdynanda, 24 IV 1846, Zl. 341, k. 145.

138 A. Tessarczyk, Rzeź galicyjska 1846 r., czyli szczegółowy opis dokonywanych morderstw, rozbojów i łupieztw, wraz z ważniejszymi wypadkami,jakie tym okropnym scenom towarzyszyły w związku z intrygami biurokracji, Kraków 1848, s. 73-74.

139 „Przegląd Rzeczy Polskich” (Paryż) 10, 10 X 1861.

140 „Szela selbst aus Rücksichten für die öffentliche Meinung nach Tarnow konfi- 
Podczas rabacji Szela dał się poznać jako świetny organizator, a wielu świadków dobrze zapamiętało jego charakterystyczną, „wojskową postawę". Brak źródłowego potwierdzenia jego pobytu w wojsku spowodowało istnienie sprzecznych opinii, przy czym osób twierdzących, że nigdy nie trzymał on karabinu w ręce, było znacznie więcej ${ }^{141}$. „A że brat jego starszy był osadzonym na gruncie ojca, więc kolej na niego wypadła być żołnierzem. Do stanu tego nie czuł powołania żadnego - opowiadała kaśliwie Gorayska - gdyż mu brakowało odwagi i posłuszeństwa, a z drugiej strony wysiliła się natura na rozum do intryg i przewrotności. Gdy widział zbliżających się ludzi, co go w rekruty brać mieli, z szybką determinacją odciął sobie sam siekierą dwa palce u ręki, i tak się ochronił i tym sposobem pozostało we wsi to monstrum" ${ }^{142}$. Podobnie brzmią inne życiorysy, w tym paryski: „Gdy jako popisowy był wzięty do wojska, uciął sobie sam palec u ręki i wróciwszy do wsi jeszcze gorszym się okazał"143. Fakt samookaleczenia jako „ucieczki” przed wojskiem potwierdził Szydłoski, opowieścią najpewniej zasłyszaną od samego Szeli: „bał się wojska, uciął sobie sam dwa najgrubsze palce u prawej ręki tak z ukosa, a jak mu się krew lała i matka się go pytała: coś ty zrobił? On nic - a na ręce nad łokciem zrobił mu się guz, krew się zsiadła, wziął sam brzytwy, przerżnął, wygniótł, krew wyszła i na tym był zdrów"144. Również Oficer nie miał wątpliwości: „Należy także sprostować, że Jakub Szela był kiedyś wojskowym. Tenże nigdy i nigdzie nie odbywał służby wojskowej. To stwierdzenie odnosi się bardziej do jego syna, który przez 14 lat był kapralem w pułku Koudelki [40 pp], więc już swoje odsłużył"145. Nie można jednak wykluczyć pełnienia przez Szelę służby wojskowej, choćby przez kilka lat. Najłatwiej jest zweryfikować wersję Oficera, zwłaszcza przy założeniu, że był nim Breinl. Otóż znając okoliczności „ucieczki” Szeli przed wojskiem, wolałby jej nie ujawniać, gdyż taka forma uniknięcia służby wojskowej była niechlubna i na pewno zachwiałaby budowany od początku przez starostę w Wiedniu pozytywny wizerunek przywódcy chłopskiego - „obrońcy monarchii”.Jeśli zaś autorem tej tezy był „zwykły” oficer, to uwierzył po

niert”, ÖStA, AVA, PHSt, fasc. 1509/1848 „Jakob Szela”, L. Sacher-Masoch do J. Sedlnitzkiego 19 XI 1847, k. 6 nlb.

141 A. Bogusz, Wieś, s. 21; P. Rysiewicz, op. cit., s. 34; S. Kieniewicz, Ruch, s. 189; i in.

142 [L. Gorayska], Szela, s. 328-329.

143 S. Kalembka, op. cit., s. 81.

${ }^{144}$ Relacja chłopa, s. 306.

145 „Auch ist zu berichtigen, daß Jacob Szela jemals Militair gewesen war. Derselbe hat nie und nirgends gedient. Dieses gilt vielmehr von seinem Sohne, der 14 Jahre bei dem Regimente Koudelka als Korporal gestanden, nun aber schon ausgedient hat", Das Polen-Attentat, s. 293. Urodzony w 1817 r. Stanisław w normalnym trybie musiał odsłużyć 10, a nie 14 lat (patrz przyp.149). 
prostu słowu chłopa, dla którego nie był to powód do chwały. W $1881 \mathrm{r}$. Constant von Wurzbach jednoznacznie stwierdził, że Szela był wysłużonym żołnierzem, a „w armii cesarskiej nabrał nawyków ze szkolenia kompanijnego, które były widoczne w całym jego postępowaniu"146. W dokumentach urzędowych Szelę określa się jako „urlopnika” (Urlauber), co można raczej jednoznacznie rozumieć, że był wysłużonym żołnierzem ${ }^{147}$. Również Janik, cytujący z akt lwowskich, wzmiankuje, że nazywano go „urlopnikiem złych obyczajów" ${ }^{148}$. Proceder okaleczania się był rozpowszechniony wśród potencjalnych poborowych w okresie wojen napoleońskich.

Od 1802 r. długość służby wojskowej w Przedlitawii określono w piechocie na 10, konnicy 12, a w artylerii na 14 lat. Obowiązek służby ciążył wtenczas wyłącznie na mieszkańcach miast prywatnych, chłopach i Żydach $^{149}$, przy czym powoływano z reguły mężczyzn od ukończonego 17 roku życia (do 40), choć zdarzały się wyjątki ${ }^{150}$. W przypadku Szeli byłby to rok 1804 lub 1805, przy założeniu, że nie był ochotnikiem, gdyż wtedy mógł trafić do wojska wcześniej. Jego pierwszy ślub odbył się w 1809 r., a bliźniaki urodziły się dwa lata później, w lipcu 1811 r. Może to wskazywać, że nie było go wtedy w domu. Kolejne dzieci rodziły się już niemal rok po roku, w grudniu 1812, kwietniu 1814, listopadzie 1815 i maju 1817 r., więc najprawdopodobniej od roku 1812 stale przebywał już w Smarzowej. Śmierć matki Szeli, mającej przecież być świadkiem okaleczania dłoni, nastąpiła w 1815 r., co potwierdzałoby tę tezę. Dodatkowe zamieszanie wprowadzają doniesienia prasy. Według gazety poznańskiej z 17 kwietnia 1846 r. Szela miał być „dawnym kapralem”"151. Jak zwykle wiadomość rozniosła się jak echo ${ }^{152}$. Z prasy płynie też ważna informacja: „Wzięty r. 1818, jako rekrut, sam sobie palce u lewej ręki uciął i tym sposobem został od służby wojskowej uwolniony", napisał redaktor

146 „bei der kaiserlichen Armee eignete er sich in der Schulung des Compagniedienstes jene Kenntnisse und jene Lebenspraxis an, welche sich in allen seinen Handlungen kundgeben. Ein längst ausgedienter Soldat", Szela Jakob, w: Biographisches Lexikon des Kaiserthums Oesterreich, red. C. v. Wurzbach, t. 42, Wien 1881, s. 32-33.

147 ,als den Gemeinde Deputierte Jakob Szela als den Urlauber”, ÖStA, AVA, PHSt, fasc. 1509/1848 „Jakob Szela”, L. Sacher-Masoch do J. Sedlnitzkiego, 19 XI 1847, k. 6 nlb.

${ }_{148}$ M. Janik, Zestanie, s. 88.

149 O. Balzer, Historia ustroju Austrii w zarysie, Lwów 1899, s. 454-455; A. Wrede, Geschichte der k. und k. Wehrmacht, (Supplement zu den „Mitteilungen des k. und k. Kriegs-Archivs"), t. 1, Wien 1898, s. 103-104.

${ }_{150}$ A. Wrede, op. cit., t. 1, s. 102.

151 GWXP 89, 17 IV 1846, s. 357.

152 „Ein ehemaliger Unteroffizier de k.k. Artillerie”, „Regensburger Zeitung” 108, 20 IV 1846, s. 447; „Münchner Politische Zeitung” 94, 21 IV 1846, s. 403; FOZ 121, 2 V 1846, s. 1194; „Kourier an der Donau. Zeitung für Niederbayern” 123, 4 V 1846; „Der Siebenbürger Bote" (Sybin) 37, 8 V 1846, s. 149. 
świetnie poinformowanej gazety z Poznania ${ }^{153}$.W prasie niemieckiej, gdzie powtórzono tę wiadomość, mowa jest z kolei o jednym palcu ${ }^{154}$, co zresztą jest drugorzędne, gdyż najważniejszy był rok zdarzenia. Może zamiast roku 1818 miał być 1808 ? O błąd w druku przecież bardzo łatwo. Data ta, jako możliwe zakończenie przez Szelę służby wojskowej, wydaje się logiczna, przez co uzyskaliśmy cezurę jego potencjalnej służby wojskowej na lata ok. 1804-1808. W aktach Rady Wojennej (Hofkriegsrath), gdzie nieraz odnotowywano próby uniknięcia służby wojskowej, do czego naturalnie należały samookaleczenia, za lata 1800-1825 nazwisko Szeli nie figuruje ${ }^{155}$. Do roku 1808 w okolicach Tarnowa prowadziło pobór rekrutów kilka jednostek. Pomocniczy okręg werbunkowy (tzw. Aushilfs-Bezirk) miał pułk piechoty nr 45 (1782-1804, rozwiązany w roku 1809). W okresie 1772-1807 również pomocniczo werbował 17 pp, podobnie jak 35 pp (1775-1807, najpierw w okolicach Tarnopola, potem Pilzna) i 36 pp (1782-1807 Tarnów, potem Jasło i Dukla) oraz 40 pp (1772-1804 Jasło; „De Vaux” rozwiązany w 1809, w latach 1776-1806 „Franz baron Lattermann”). W przypadku kolejnych dwóch pułków piechoty - 10 (pomocniczy Wieliczka-Myślenice) i 12 (połówkowy Rzeszów) - Alphons v. Wrede podał, że pobierały one rekruta z interesujących nas terenów w latach 1807-1817, jednakże analiza list musterunkowych (tzw. Musterlisten) wykazała, że już w 1804 r. byli tam chłopi z rejonów Bochni i Tarnowa. Ponadto w latach 1808-1817 pomocnicze lub połówkowe okręgi werbunkowe w Rzeszowie miały pułki piechoty $\mathrm{nr} 8$, 29, i $26(1782-1804)^{156}$. Kwerenda wykazała, że w pułkach 10, 12, 26, 36 i 40 nie było poborowych z Siedlisk ani Smarzowy ${ }^{157}$. Wreszcie w wykazie żołnierzy wziętych do niewoli pod Ulm w pułku 35, w 3 kompanii fizylierów natrafiono na nazwisko Szeli ${ }^{158}$. Zapisane zostało $\mathrm{w}$ tzw. „Standestabelle” z października 1805 r., gdzie odnotowywano wszelkie zmiany stanów osobowych, czyli chorych, dezerterów, etc. Zapis nie jest jednak jednoznaczny, ,Sz” wygląda bowiem, jakby skryba chciał napisać

153 GWXP 92, 21 IV 1846, s. 372 [2].

154 „Um dem Militärdienste, zu dem er im Jahr 1818 herangezogen werden sollte, zu entgehen, hieb er sich einen Finger der linken Hand ab", FOZ 114, 25 IV 1846, s. 1127-1128; i in.

155 ÖStA, oddz. Kriegsarchiv, zespół Hofkriegsrath, Indizen 1805-1819, hasło: Selbstverstümmelung i Mutilanten.

${ }^{156}$ A. Wrede, op. cit., t. 1, s. 164 (8 pp), 181 (10 pp), 198 (12 pp), 233 (17 pp); 299 (26 pp), 324 (29 pp), 366 (35 pp), 375 (36 pp), 401 (40 pp).

15710 pp za lata 1806-1808 (ÖStA, oddz. Kriegsarchiv [dalej: KA], Personalunterlagen [Pers], Musterlisten [ML], kart. 715-716), 1804-1805 brak wykazów; 12 pp 1804 i 1806 (ÖStA, KA, Pers, ML, kart. 896-898); 26 pp 1804 i 1806 (ÖStA, KA, Pers, ML, kart. 2157-2159); 36 pp 1804 i 1806 (ÖStA, KA, Pers, ML, kart. 3297-3299); 40 pp 1804 i 1806 (ÖStA, KA, Pers, ML, kart. 3594-3595).

158 ÖStA, KA, Pers, Standestabelle (35 pp za 1805), kart. 3244. 
„Sch”, ale nagle rozmyślił się i wyszło z tego „Suela”. Podobne omyłki w rękopisach urzędniczych to rzecz wręcz nagminna, a chłopa smarzowskiego bardzo często określano z niemiecka „Schela” czy „Schella”. Analiza dokumentów wykazała, że 3 kompania powstała z naboru letniego 1805 r., z cyrkułu tarnowskiego. Choć nie padają tam nazwy miejscowości, wniosek płynie z porównania list z poprzednich lat. Podobnie jak w innych pułkach w roku 1805, nie stworzono dla niej listy musterunkowej, więc na nic zdały się porównania stanu z sąsiadujących okresów, w wykazach z lat $1804-1806^{159}$. Był to okres wojny, kiedy w pośpiechu formowano jednostki wobec zbliżających się Francuzów, więc takie uproszczenie może być zrozumiałe. Rekonstruując wydarzenia, wydaje się, że Szela zamusztrowany został w 1805 r. i niedługo potem w bitwie pod Ulm (8-15 X 1805) trafił do niewoli, skąd po wypuszczeniu wrócił do domu, gdzie się okaleczył. Fragmentaryczność wyszukanych źródeł powoduje jednak, że wobec tej kwestii należy zachować dystans.

Z kwestią tą nierozerwalnie złączone jest pytanie, którą rękę okaleczył sobie Szela. Analiza zachowanych rycin i przekazów wskazała jednoznacznie na lewą dłoń, odrąbane siekierą palce serdeczny i środkowy oraz odkształcony (odstający) palec środkowy ${ }^{160}$.

Od początku lipca $1846 \mathrm{r}$. dwór zaczął nagradzać tych z poddanych, którzy podczas powstania Polaków wykazali się lojalnością. Jednym z pierwszych wyróżnionych był starosta Breinl, który 18 lipca 1846 r. otrzymał krzyż orderu Leopolda z uwolnieniem od taksy. Było to niejako „na osłodę", gdyż w tym samym dniu przeniesiono go do Brna ${ }^{161}$. Do dzisiaj zdania są podzielone, czy również Szelę obdarzono medalem. W 1896 r. Ostaszewski-Barański, który wymienił poprawnie większość wynagrodzonych poddanych ${ }^{162}$, dodał, że „największy złoty medal honorowy z wielką wstęgą" przyznany został Szeli 5 sierpnia 1847 r. jako „korona” odznaczeń cesarskich ${ }^{163}$. Wprowadził on czytelnika najzupełniej świadomie w błąd, każdy bowiem, kto choć raz przeglądnął szematyzmy dworu wiedeńskiego, zauważyć musi mistyfikację, gdyż nie było takiego odznaczenia. W literaturze pierwszym badaczem kwestionującym prawdziwość tego „faktu” był R. Rozdolski ${ }^{164}$, a po nim rozsądnie odniósł się do sprawy

159 ÖStA, KA, Pers, ML (35 pp za lata 1804-1806), kart. 3193-3195 oraz ÖStA, KA, Pers, Assentlisten/Transferirungslisten (35 pp za 1805), kart. 3245.

160 Por. praca autora pt. Twarze Jakuba Szeli, która ukaże się w PH $(2013,4)$.

161 „Wiener Zeitung” 209, 31 VII 1846, s. 1; „Gazeta Lwowska” 90, 6 VIII 1846. Jego miejsce zajął starosta z Przemyśla Karl Czetsch de Lindenwald.

${ }^{162}$ K. Ostaszewski-Barański, Krwawy, s. 274-280.

${ }^{163}$ Ibidem, s. 280-281, 283.

${ }^{164}$ R. Rozdolski, rec.: Michał Janik, Zesłanie, s. 442. 
Kieniewicz, twierdząc, że Wiedeń nie chciał Szeli nagradzać, pozbywając się go z Galicji poprzez nadanie ziemi na Bukowinie ${ }^{165}$. Wydaje się, że ogromny wpływ na utrwalenie poglądu o istnieniu tego odznaczenia miało odlanie przez byłego więźnia Kufsteinu Henryka Dmochowskiego (vel Sanders) ${ }^{166}$ niezwykłego medalionu pomyślanego jako spluwaczka, z wizerunkami Szeli i Metternicha, na szyjach których artysta „zwiesił” cesarskie medale ${ }^{167}$. Dmochowski, obok bezsprzecznej chęci dopieczenia decydentom wiedeńskim, chciał też zarobić na swoim dziele, więc odlał znaczną ich liczbę, i to jeszcze w kilku wymiarach. Na poparcie tezy o nieistnieniu „medalu” posłużymy się wnioskiem sporządzonym przez Zaleskiego o nagrodach dla lojalnych poddanych, gdzie naturalnie nie padło nazwisko Szeli, za to znalazł się Joseph Janocha, mający otrzymać 50 florenów m.k. ${ }^{168}$ Chłop ten był jednym $\mathrm{z}$ najaktywniejszych przywódców podczas rabacji, przy czym w Galicji głośno było o jego krwawych "metodach" działania. Janocha pojawił się też na decyzji cesarskiej ${ }^{169}$, ale już w urzędowych gazetach „Wiener Zeitung” i „Gazecie Lwowskiej” nie było o nim jakiejkolwiek wzmianki. Na piśmie cesarza przy jego nazwisku widnieje dopisane innym charakterem pisma „N”, co najprawdopodobniej oznacza „nein” i mogło zostać skreślone na przykład przez arcks. Ludwika. Tymczasem w stolicy zrozumiano, że chłop ten kategorycznie nie zasługuje na wyróżnienie. Przy Szeli zadziałały zapewne podobne mechanizmy - chciano sprawę przeczekać, dlatego o nagrodzie zaczęto rozmawiać dopiero od lata $1847 \mathrm{r}$.

Od końca lipca 1846 r. zabrakło Szeli opiekuna, Breinla. Musiał to mocno odczuwać, gdyż 29 grudnia 1846 r. jego żona napisała prośbę do hr. Rudolfa Stadiona, nadzwyczajnego pełnomocnego komisarza dworskiego Galicji, o wypuszczenie męża i podjęcie dochodzenia z wolnej stopy (nie został powiadomiony o wynikach śledztwa). Jedyną reakcją na to pismo było pozwolenie na ich wspólne zamieszkanie w Tarnowie. W lecie 1847 r., w drugim roku swojego dziwnego odosobnienia, Szela, dalej nie wiedząc, że został uniewinniony, wystosował list do cesarza. Skarżył się na wiele spraw, w tym, że „mieszka w sieniach”, gdyż „drzwi całą noc otworzone są z przyczyny niegodziwych policyanow", etc ${ }^{170}$.

165 S. Kieniewicz, Ruch, s. 321.

166 T. Szubert, „Polnische Gefangene”, s. 120 n.

167 Pierwowzór medalu (drzeworyt) stworzył najprawdopodobniej Jan Nepomucen Lewicki wspólnie z H. Dmochowskim. Więcej na ten temat w Twarze Jakuba Szeli.

168 ÖStA, AVA, Hofkanzlei, IV.D.5 Medailen, kart. 521, Protokół 21379 z 24 VI 1846, Kabinetsschreiben 22991/1280/846.

169 ÖStA, AVA, Hofkanzlei, IV.D.5 Medailen, kart. 521, Protokół 21379, decyzja Ferdynanda z 24 VI 1846, nr 526, Zl. 14658/1846.

${ }^{170}$ M. Janik, Słowa, s. 79. 
Skargi te poruszyły ociężałą biurokrację. 30 marca 1847 r. Karl Czetsch skreślił znamienne słowa:

W świeżej jeszcze pamięci są przerażające wypadki, jakie zdarzyły się zeszłego roku, w których Szela odegrał znaczną rolę i - obojętnie: słusznie czy nie - wyrósł na sławę niemal europejską. [- - Biorąc całość pod uwagę, byłoby nawet wskazane i pożądane, ażeby Szelę i na przyszłość usunąć całkowicie z okolicy, w której zażywa tak ogromnego miru, a to zarówno w jego własnym interesie, jak i spokoju publicznego, co dałoby się łatwo zrobić, gdyby w dobrach kameralnych wschodniej części państwa przydzielono mu gospodarstwo poddańcze, którego obszar równoważyłby odpowiednio obecnie posiadane gospodarstwo ${ }^{171}$.

Starosta skonkretyzował pomysł usunięcia Szeli w cień, myśl, którą prawdopodobnie pierwszy wysunął nadkomisarz Joseph Piringer z Kolbuszowej w kwietniu $1846 \mathrm{r}^{172}$

Okazuje się jednak, że wyekspediowanie Szeli do „wschodniej części państwa" nie było jedyną opcją, więcej - w rzeczywistości było jedynie wariantem zastępczym. Nowo mianowany 21 kwietnia 1847 r. gubernator Galicji hr. Franz Stadion-Warthausen, jeden z najwybitniejszych polityków austriackich tamtych czasów, zainicjował przesiedlenie Szeli dużo bliżej, pod Cieszyn. „W interesie własnym i rządu - pisał on w październiku 1847 r. - został Szela zobowiązany do określenia się, czy jest gotowy przenieść się do swojej nowej ojczyzny w regionie Śląska, gdzie polski jest językiem krajowym"173. Wobec szczupłości przekazów nie da się prześledzić dokładnie tego wątku. Czym kierował się F. Stadion w wybraniu tej lokalizacji? Wydaje się, że było kilka logicznych przesłanek. Po pierwsze tereny Czech i Moraw ze Śląskiem austriackim, gdzie leżał Cieszyn, cieszyły się nad Dunajem opinią najwierniejszych (obok Tyrolu) krajów monarchii. Argumentem mogło też być, że po brutalnej pacyfikacji chłopów na Śląsku Opawskim wiosną 1847 r., teren mógł zostać uznany za bezpieczny ${ }^{174}$. Ponadto, co wydaje się niezwykle istotne, były starosta Breinl został przeniesiony właśnie do Brna, czyli z Szelą znajdowałby się w tej samej jednostce administracyjnej i potrafiłby nad nim sprawować nadzór. F. Stadion wiedział przecież, że Szela słuchał się byłego starosty we wszystkim, mógł

${ }^{171}$ Idem, Zesłanie, s. 112-113.

172 Ibidem, s. 89; TBar, 29, k. 129, J. Breinl do Landespräsidium 9 VI 1846, Zl. 3905/ggg, oraz L. Lažanský do F. Kriega 13 VI 1846.

173 ÖStA, oddz. Haus-, Hof- und Staatsarchiv, zespół Staats-Konferenz „a” (dalej: HHStA), kart. 66, dok. 1015/1847, F. Stadion do K. Inzaghiego, 10 X 1847. Raport ten zaginął, cytat za: R. Rozdolski, rec.: Janik Michał, Zesłanie, 448.

174 S. Kieniewicz, Ruch, s. 331. 
więc z nim ustalić tę kwestię. Za takimi przenosinami przemawiał też język potencjalnych sąsiadów Szeli - pod Cieszynem chłopi mówili po polsku. Gubernator zaś najwyraźniej nie chciał karać sześćdziesięcioletniego człowieka, oprócz tego był „państwowcem” i pamiętał o zasługach Szeli, jakie tenże oddał monarchii. Ta życzliwość gubernatora dla chłopa smarzowskiego widoczna będzie jeszcze później, podczas jego pobytu na Bukowinie.

Pismo F. Stadiona z „pomysłem cieszyńskim” zaginęło, zachowała się jednak znamienna opinia Sacher-Masocha przeznaczona dla ministra policji Sedlnitzkiego z listopada 1847 r., w której poruszył on wszystkie intencje Stadiona:

Na pytanie zaś, czy Szela powinien zostać w swojej dotychczasowej ojczyźnie, przyłączam się do poglądu Pana Gubernatora, że bez zagrożenia osobistego i z najwyższych względów państwowych nie powinno mieć to miejsca. Przesiedlenie do cyrkułu cieszyńskiego w dobrach Jego cesarskiej Mości arc. Albrechta w danej chwili nie jest wykonalne, ponieważ w myśl pisma Jego cesarskiej Mości do Pana Gubernatora nie ma tam żadnego wolnego gospodarstwa. Jednakże nie popieram pomysłu Pana Najwyższego Kanclerza przesiedlenia go do Czech, na które zresztą Szela sam wyraził zgodę, ponieważ na tamtych terenach, gdzie jeszcze w tej chwili wzbudza on emocje, przysłużyłoby się to tylko wrogiej partii, stąd pośrednie uznanie jego winy, czym będzie odesłanie go z kraju [Galicji], dostrzeżone zostanie jako kara, która wyrażona na drodze prawnej będzie miała wymowę polityczną. Najrozsądniejsze, ostateczne rozwiązanie leży według mnie w przydzieleniu mu gospodarki na Bukowinie jako dziedzicznej własności $\mathrm{w}$ formie samowystarczalnego gospodarstwa fundus instructus ${ }^{175}$, zwolnienie z kosztów przesiedlenia i zapewnienie o zniesieniu świadczeń zarówno dla niego, jak jego potomków, aby miał odczucie pełnego zadośćuczynienia i odebrał to osiedlenie jako prezent wynikający z łaski cesarskiej. Poprzez ten wybieg dynamicznie oczyszczona zostanie scena z fatum, bo przecież nie w każdym przypadku wydalenie z kraju wzbudza taką sensację, które tym trudniejsze jest do uniknięcia, kiedy polski chłop z całej duszy przywiązany jest do roli i ziemi, więc Szela, podobnie do swoich licznych zwolenników, wbrew sprzyjającym okolicznościom, musi odbierać to jako karę. $\mathrm{O}$ ile mi jest wiadomo, Pan Gubernator ma na tę sprawę podobny pogląd, i w celu wyszukania gospodarki w dobrach kameralnych na Bukowinie już porozumiał się Panem Administratorem tych dóbr. Realizacja tego projektu, który zaakceptowany został przez Szelę, powinna być wykonana bezzwłocznie ${ }^{176}$.

175 Instructus fundus - w pełni wyposażone gospodarstwo rolne, Herders Conversations-Lexicon, t. 3, Freiburg im Breisgau 1855, s. 423.

176 „In der Frage, ob Szela in seiner bisherigen Heimat zu belassen sei, kann ich 
Po raz pierwszy sprawa została podniesiona na obradach Konferencji Stanu 3 stycznia 1848 r. Kanclerz hr. Karl Inzaghi poinformował, że przeniesienie Szeli leży w interesie rządu, z tego tytułu bowiem był on narażony na wielokrotne oszczerstwa (,vielfache Verlogenheiten”) ${ }^{177}$. Wyraził on zrozumienie dla władającego Cieszynem arcks. Albrechta von Österreich-Teschen ${ }^{178}$, niechcącego mieć w swoich dobrach człowieka „von so eigentlichen Berümtheit" ${ }^{\prime 179} .10$ stycznia 1848 r. na kolejnej naradzie Inzaghi przedstawił pismo gubernatora Galicji z 21 grudnia $1847 \mathrm{r} .{ }^{180}$ „Stało się naglące - pisał F. Stadion świadomy niewykonalności pomysłu «cieszyńskiego» - przenieść gdzieś Szelę, a skoro nie można go zostawić w domu

mich der Ansicht des Herrn Landes Gouverneurs, daß ohne Gefährdung seiner persönlichen Sicherheit und aus höheren Staatsrücksichten nicht geschehen könne, anschließen. Die für ihn Auftrag gebrachte Uibersiedlung in den Teschner Kreis auf eine Herrschaft Se. kaiserlichen Hoheit des Durchlauftigsten Herrn Erzherzogs Albrecht ist für die Augenblick nicht ausführbar, weil sich laut einer im höchsten Auftrage Se. kais. Hoheit an den Herrn Landes Gouverneur ergangenen Eröffnung auf höchstdessen Gütern keine erledigte Bauernwirtschaft befindet. Ich hatte aber auch dieser Uibersiedlung, für welche übrigens Szela seine Geneigtheit erklärt hat, nicht das Wort reden können, und kann auch die von dem Herrn obersten Kanzler in Anregung gebracht Abschaffung nach Böhmen nicht unterstützen, weil sie in der Gegend wo Szela noch gegenwärtige Meinung erzeugen, und der feindlichen Parthei Gelegenheit biethen würden, darin eine indirekte Anerkennung seiner Schuld, und in der Landesverweisung einen Strafe wahrzunehmen, welche man im gerichtlichen Wege auszusprechen aus politischen Gründen geschaut hat. Das zweckmäßigste Auskunftsmittel liegt nach meinem Dafürhalten in der Zuweisung einer Bauernwirtschaft in der Bukowina als erbliches Eigenthum mit einem vollständigen fundus instructus, kostenfreier Uibersiedlung und der Zusicherung der Abgabenfreiheit für sich und seine Nachkommen der Art, daß er sich für vollkommen entschädigt halten, und diese Ansiedlung als ein Geschenk der kaiserlichen Gnade auszunehmen in der Lage ist. Durch diesen Ausweg ist er dem Schauplatze seiner Verhängniß vollen Thätigkeit entrückt, und doch nicht der jedenfalls Aufsehen erregenden Landesverweisung Preis gegeben, welche um so mehr zu vermeiden ist, als der polnische Bauer mit ganzer Seelen seinem Grund und Boden hängt, und Szela so wie sein zahlreicher Anhang dieselbe selbst unter den günstigsten Verhältnissen für eine Strafe ansehen müßte. So viel mir bekannt, ist der Herr Landes-Gouverneur dermal von derselben Ansicht geleitet, und hat sich wegen Ausmittlung einer Bauernwirtschaft auf einer Kameral-Herrschaft in der Bukowina mit dem mit dem Herrn Kameral Gefällen Administrator bereits ins Einvernehmen gesetzt. Die Realisierung dieses Projektes, für welche auch Szela seine Zustimmung erklärt hat, dürfte keinem Anstande unterliegen", ÖStA, AVA, PHSt, fasc. 1509/1848 „Jakob Szela”, L. Sacher-Masoch do J. Sedlnitzkiego, 19 XI 1847, k. 7-9 nlb.

177 ÖStA, HHStA, kart. 67, dok. 19/848, Protokół Konferencji Stanu z 6 I 1848, k. 50, s. 1.

178 Albrecht von Österreich-Teschen (1817-1895), feldmarszałek, najstarszy syn arcks. Karla Ludwiga, brata cesarza Franciszka II/I. Od 1847 książę cieszyński, w latach 1851-1860 gubernator Węgier. W 1866 r. odniósł zwycięstwo pod Custozzą. W 1856 r. założył w Żywcu browar, J. Golec, S. Bojda, Słownik biograficzny ziemi cieszyńskiej, t. 3, Cieszyn 1998, s. 19.

179 Ibidem.

180 ÖStA, HHStA, kart. 67, dok. 35/848, Protokół Konferencji Stanu z 10 I 1848, k. 105. 
ani dłużej przetrzymywać w więzieniu, znalazłem inne rozwiązanie i z pomocą administratora Funduszu Kameralnego [Galicji i Bukowiny] radcy dworu Franza v. Pöchera ${ }^{181}$, w dobrach państwowych Sołka na Bukowinie udało się wyszukać odpowiedni grunt na osiedlenie Szeli i jego rodziny. Tenże wyraził zgodę na przenosiny i natychmiastowy wyjazd" ${ }^{182}$. F. Stadion, forsując ten wariant, w międzyczasie realizował plan awaryjny, „bukowiński”. Szela już 26 września 1847 r. zapoznał się ze wstępnym protokołem dotyczącym przesiedlenia do tego kraju ${ }^{183}$, sporządzonym przez zarządcę dóbr kameralnych w Czerniowcach Wenzela Schaulawego ${ }^{184}$. Proponowano mu tam objęcie w dobrach kameralnych (państwowych) 30 mórg pod osadą Glitt oraz blisko 2 morgi w samej wsi. Mowa też była o tym, że po upływie 10 lat wolnizny wszystkie należności, które w drodze rozporządzeń Kancelaria Nadworna ustaliła dla nowych osadników, powinny być skwapliwie oddawane. Po przybyciu na Bukowinę miano sporządzić protokół przejęcia ziemi. Na trzecim, ostatnim spotkaniu Konferencji Stanu w sprawie Szeli Inzaghi zgodził się z gubernatorem, aprobując przeniesienie chłopa do ustalonego miejsca. Było to, jak planowano pierwotnie we Lwowie, nadanie z łaski cesarskiej, co 21 stycznia 1848 r. cesarz skrupulatnie podpisał na podsuniętym mu dokumencie ${ }^{185}$. Nieco wcześ-

${ }^{181}$ Franz v. Pöcher, przewodniczący k.k. Vereinigte Cameral-Gefällen-Verwaltung für Galizien und die Bukowina z siedziba we Lwowie, Hof- und Staats-Handbuch des österreichischen Kaiserthumes, Wien 1848, cz. 1, s. 488.

182 „es dringend war, Szela irgend wo hin zuweisen, da es nicht thunlich war, ihn nach Hause zu lassen oder länger in Haft zu behalten, habe ich ein anderes Auskunftsmittel gesucht, und es ist mir durch Mitwirkung des Kaal-Gefällen-Administrators, Hofrats v. Pöcher gelungen, auf der von Galizien entlegenen Staatsherrschaft Solka in der Bukowina, einen Ansiedlungsgrund für Jakob Szela und seine Familie ausfindig zu machen. Derselbe hat sich bereit erklärt, dahin auszuwandern, und wird gleichzeitig aufgefordert, ohne Verzug dahin abzugehen”, ÖStA, AVA, PHSt, fasc. 1509/1848 „Jakob Szela", F. Stadion do J. Sedlnitzkiego, 21 XI 1847, k. 20, s. 2 nlb.

183 ÖStA, AVA, PHSt, fasc. 1509/1848 „Jakob Szela”, Wstępne warunki przesiedlenia Szeli do Glittu, 26 IX 1847, w raporcie galicyjskiego Administratora Funduszów Kameralnych z 26 XII 1847, k. 14 nlb. Glit (niem. Glitt, rum.Clit), wieś w powiecie (w 1848 r. cyrkuł) radowieckim na Bukowinie, oddalona $4 \mathrm{~km}$ od Sołki, SGKP, t. 2, Warszawa 1881, s. 592.

184 Wenzel Schaulawy, Vorsteher k.k. Cameral-Bezirks-Verwaltung für den Bukowinaer Kreis z siedzibą w Czerniowcach, ibidem, s. 492.

185 ÖStA, HHStA, kart. 67, dok. 64/848, Protokół Konferencji Stanu z 15 I 1848, k. 189, s. 1. Dokument parafowali wszyscy członkowie powstałej w 1835 r. tajnej rady regencyjnej, tzw. Konferencji Stanu (Staats-Konferenz), ponieważ cesarz Ferdynand wobec swojej choroby (m.in. epilepsji) nie był w stanie samodzielnie rządzić. 16 stycznia złożył podpis arc. Ludwig, brat poprzedniego cesarza Franciszka II/I, uważający się za najważniejszego członka Konferencji; 17 stycznia z kolei mający przemożny wpływ na sprawy wewnętrzne monarchii, główny oponent Metternicha, hr. Franz Anton von Kolowrat-Liebsteinsky; 18 stycznia kanclerz ks. Metternich oraz arcks. Franz Karl, młodszy brat chorego Ferdynanda (ojciec Franciszka Józefa). 
niej, 5 listopada 1847 r., w starostwie tarnowskim aktuariusz z przypadku, były dyrektor policji w Krakowie Wohlfahrth ${ }^{186}$, w myśl wskazówki prezydialnej z 26 października 1847 r. spisał z chłopem protokół, w którym tenże zdecydował się na wyjazd na Bukowinęę ${ }^{187}$. Szela podpisał się jak zwykle krzyżykiem, a urzędnik zastosował znaną nam formułę „Namensfertiger" ${ }^{188}$. Wreszcie 14 grudnia $1847 \mathrm{r}$. Szela postawił kolejny krzyżyk pod protokołem o „ostatecznych warunkach przesiedlenia”. o ten dokument upominał się od Janika Rozdolski ${ }^{189}$.

Nie ulega wątpliwości, że nawet pomimo zastrzeżeń i ograniczeń darowizna ta była nagrodą, wstydliwą, ale zawsze nagrodą, którą monarchia zrewanżowała się swojemu wiernemu obrońcy. Bezsprzeczne też jest, że zwyciężył interes państwa, gdyż niewielkim kosztem pozbyto się niewygodnego człowieka z „zagrożonych” terenów.

Szelę dosłownie w ostatniej chwili przed wybuchem Wiosny Ludów przeniesiono w miejsce, gdzie „zsyłano” niepokornych i niewygodnych urzędników, na koniec austriackiego świata. Bukowina była krainą o dużym potencjale, gdyż osadnictwo zapoczątkowane przez Józefa II i Marię Teresę spowodowało, że w XIX w. stała się ona „ogniskiem domowym wielu narodowości" ${ }^{190}$. Szela nie był jednak tam mile widziany.Ziemianie na Bukowinie wyrazili wobec starosty w Czerniowcach Georga Ißetscheskula ${ }^{191}$ obawy z tytułu jego przyjazdu. F. Stadion zarządził więc, na wszelki wypadek,

${ }^{186}$ Phillip Wohlfahrth w 1847 r.tzw. nadliczbowy (überzählig), rzeczywisty sekretarz gubernialny, Hof- und Staats-Handbuch des österreichischen Kaiserthumes, Wien 1847, cz. 1, s. 391. Urzędnik ten przydzielony został do Tarnowa w marcu 1846 r., M. Sala, op. cit., s. 308.

187 ÖStA, AVA, OPB, kart. 30, fasc. 5720/1854 „Jakob Szela”, Protokół sporządzony W Tarnowie 5 XI 1847, k. 14, s.1-2. O kwestiach tych pisze też Janik (Zesłanie, s. 114115), ale jego relacja obarczona jest błędami.

188 Ibidem.

189 Ostateczny protokół o warunkach przesiedlenia J. Szeli na Bukowinę, 14 XII 1847; Rozdolski (rec.: Janik Michał, Zesłanie, s. 448) widział ten dokument we Lwowie w aktach z 1851 r., jego odpis znajduje się też w ДАЧО, kart. 1, fasc. 10567/1851.

${ }_{190}$ M. Petraru, Polacy na Bukowinie w latach 1775-1918, Kraków 2004, s. 7.

191 Od 1840 do 1849 r. starostą bukowińskim był G. Ißetscheskul. Po nim prowizorycznym kierownikiem kraju został Eduard Bach, brat osławionego Alexandra. W 1849 r. zmienił go H. Henniger, pełniąc funkcję do marca 1853, kiedy zastąpił go Franz Schmück. Prowizorium trwało do 10 marca 1854 r., kiedy powołano niezależny bukowiński rząd krajowy. Schmück był pierwszym samodzielnym namiestnikiem Bukowiny. W lutym 1858 r. zastąpił go Carl Rothkirch-Panthen. Na krótko Bukowina znów poddana została zwierzchności Lwowa (kwiecień 1860-luty 1861). W maju 1860 r. Rothkirch opuścił Czerniowce, a zastąpił go Jakob Mikuli, wreszcie w marcu 1861 r. namiestnikiem został Wenzel Martina, R.F. Kaindl, Geschichte der Bukowina, cz. 3: Die Bukowina unter der Herrschaft des österreichischen Kaiserhauses (seit 1774), Czernowitz 1898, s. 26-28; J. Polek, Zur Frage der Errichtung eines röm.-kath. Bistums in der Bukowina, ,Jahrbuch des Bukowiner Landes-Museums"16, 1908 [1909], s. 32 n. 
niewpadający w oczy dozór nad chłopem oraz nakazał ograniczyć Szeli możliwość opuszczania miejsca zamieszkania ${ }^{192}$. To jednak właścicielom ziemskim nie wystarczyło. Szela „w oczach naszego nieuczonego ludu pisali ponownie do Ißetscheskula 22 marca 1848 r. - objawia się nie inaczej jak zwycięski wódz, ktoś w rodzaju króla chłopskiego, człowiek, któremu poprzez tragiczne wydarzenia w Galicji, powiększone przez potęgującą wszystko famę, fantazja naszych chłopów przypisuje bajeczną wprost moc, której według nich nie omieszka użyć na ich korzyść, moc, która zdoła uwolnić ich ze wszystkich zobowiązań poddańczych wobec panów i rządu, gwałtownie zrzucić narzucony porządek"193. Właściciele prosili o odesłanie Szeli do innej części monarchii, gdzie w danej chwili stanowiłby mniejsze zagrożenie ${ }^{194}$. Tydzień później gubernator stanowczo się temu przeciwstawił, twierdząc, że Szela nie został zesłany na Bukowinę przez rząd, lecz osiedlił się tam jako rolnik na własne życzenie, przy czym nie opuścił Galicji naznaczony piętnem przestępstwa. Dowodził, że Szela w swoim prostym rozumowaniu doszedł do wniosku, że w Galicji będzie obiektem nienawiści i trwogi, przyczyną stałego wzburzenia myśli. Chłop zażyczył sobie przeniesienia tam, gdzie szlachta, mieszczanie i stan chłopski są spokojni, a on sam nie stanie się przedmiotem niechęci i będzie mógł w pokoju wycofać się z życia ${ }^{195}$.

6 lutego 1848 r. Szelowie wyruszyli w podróż bez powrotu. Chłop od początku planował wyjazd do Glitu tylko z żoną i małoletnim synem ${ }^{196}$.

${ }^{192}$ M. Janik, Zesłanie, s. 117.

193 „eines Mannes, der in den Augen unseres unwissenden Landvolke nicht anders, denn als ein siegreicher Volksführer, als eine Art Bauernkönig erscheint; eines Mannes dem die durch die letzte traurigen Ereignisse in Galizien und die alles vergrößernde Fama aufgeregte Pfantasie unserer Bauern eine fabelhafte Macht beimisst, und bei ihm folgerecht auch die Vorstellung erwecken muß, daß er diese Macht auf zu ihre Gunsten gebrauchen werde, um sie vermöge derselben von allen ihren Pflichten gegen Grundherrschaften und Staatsregierung, von allen Fesseln der gesetzlichen Ordnung gewaltsam zu befreien", ДАЧО, kart. 2, fasc. 3012/1848, Petycja właścicieli ziemskich do G. Ißetscheskula, 22 III 1848, k. 4-6.

${ }^{194}$ Ibidem.

195 „Szela ist nicht von der Regierung in die Bukowina verwiesen, sondern seinem Wünsche gemäß auf einem Staatsgüte als Bauer angesiedelt worden, er hat Galizien nicht mit der Makel eines Verbrechers verlassen. [- - ] Szela, der nie schlechte Absichten hatte, der mit schlichtem Verstande ein ruhiges Urteil verbindet, daselbst zur Erkenntniß gekommen, daß er in Galizien der Gegenstand des Hasses und der Furcht, der Anlaß zu steter Aufregung im verschiedensten Sinne wäre und hat daher selbst gewünscht, in einer Gegend angesiedelt zu werden, wo sich Adel, Bürger und Bauernstand ruhig verhielt, wo er somit weder ein Gegenstand des Hasses noch der Furcht sein kann, ihm es daher gegönnt ist, in Frieden zurückgezogen zu Leben", ДАЧО, kart. 2, fasc. 3012/1848, F. Stadion do G. Ißetscheskula, 29 III 1848, k. 2-3.

196 ÖStA, AVA, PHSt, fasc. 1509/1848 „Jakob Szela”, Wstępne warunki przesiedlenia Szeli do Glittu, 26 IX 1847, k. 12 nlb. 
Według urzędników w drogę wybrał się z dwojgiem dzieci ${ }^{197}$, Józefem, i podobno - z małoletnią córką ${ }^{198}$. Już wcześniej stwierdziliśmy, że wydaje się wątpliwe, aby Jakub miał z Salomeą inne dzieci prócz Józefa. Chodziłoby więc o urodzoną w 1815 r. Katarzynę. Zarówno jednak w aktach urzędowych, jak księgach metrykalnych na Bukowinie nie udało się odnaleźć jakichkolwiek śladów wskazujących, że zamieszkała tam z ojcem. Szydłoski pamiętał za to coś zupełnie innego: „Stanisław, syn, był tam u niego ze Smarzowej 2 razy i dostał za pierwszym razem 2 stówki [zł reńskich, florenów monety konwencyjnej], jedną dla siebie, a drugą dla siostry Kasi, ale [jej] nie dał.Jak drugi raz poszedł, kazał mu ojciec przysiąc na P. Jezusa czy dał, on przysiągł, że dał i jeno 2 tygodnie żył [zmarł w 1853 r.]. Za to jak wrócił, siostra pisała do Szeli, jej nie dał Staszek 100 zł ani nic - tak on jej stamtąd przysłał na nowo 100 reńskich"199. Czyli Katarzyna albo została w domu i później, jak wieść gminna niosła, wyjechała do Ameryki ${ }^{200}$, albo pojechała z nim i wróciła. Nie wydaje się to jednak prawdopodobne z Szelą pojechać musiała inna dziewczyna. Przemawia za tym pewien zapis w sołeckiej księdze ślubów. Otóż w lutym 1858 r. dwudziestoletnia Anna Włosicz, której matką była Maria Niewiarowska (Niewerowska), poślubiła Michaela Schmidta ${ }^{201}$. Mogłoby to oznaczać, że Szelowie pojechali z Anną, skoligaconą z żoną Szeli Salomeą z domu Niewiarowską. Oczywiście pozostaje to tylko w sferze przypuszczeń.

10 maja 1848 r. w sołeckim zarządzie dóbr ziemskich spisano z Szelą protokół przejęcia ziemi, po niemiecku i niezbyt dobrą polszczyzną ${ }^{202}$. Na końcu polskojęzycznej wersji znalazł się dopisek: „Dopóki nie nastąpi wysoka decyzja, protokoł ten nie zostanie podpisany" i tym samym charakterem pisma złożony został autograf „Jakob Szela” ${ }^{203}$. W wersji niemieckiej aktu dopisano więcej: „Jakub Szela stwierdził, że Jego Ekscelencja Gubernator zapewniał go, że otrzyma dotację ziemską zwolnioną z czynszu (opodatkowania), dlatego protokołu nie podpisze, ale pomimo to ziemię obejmie"204.

${ }^{197}$ M. Janik, Zesłanie, s. 116.

198 Ibidem, s. 118.

199 Relacja chłopa, s. 309.

200 J. Pałosz, Szelowie ze Smarżowej, ,,Gazeta Krakowska” 22 IV 1994.

${ }^{201}$ Sächsisches Staatsarchiv in Leipzig, Deutsche Zentralstelle für Genealogie, Bukowina, Solka, Katholisch (dalej: ZGL), Getrennte 1856-1908, t. 3795. Ślub odbył się 14 lutego $1858 \mathrm{r}$.

202 ÖStA, AVA, OPB, kart. 30, fasc. 5720/1854 „Jakob Szela”, Protokół przejęcia ziemi przez Szelę w Glitcie, 10 V 1848 r. (załącznik do pisma W. Madurowicza do A. Gołuchowskiego z 26 VI 1854, nr 25373), k. 3-4.

${ }^{203}$ „Bis zur hoherer Entschließung wurde daß oryginal Protokoll angefertigt belassen", ibidem.

${ }^{204}$ "Jakob Szela wendet ein, daß ihn der Grund-Dotation von Se. Exzellenz dem Hr. Landes-Gouverneur zinsfrei zugesichert worden sey, und daß er deßhalb die 
Właśnie wtedy Szela, z synem Józefem - bo to on musiał się „wypowiedzieć" pod protokołami - dowiedzieli się, że zarówno on, jak i jego potomstwo nie zostali zwolnieni ze świadczeń. Najwyraźniej Szela padł ofiarą „gierek” niedarzących go sympatią starosty Czetscha i Wohlfahrtha. Na nieżyczliwość starosty wskazywać może choćby wzmiankowana skarga Szeli podczas internowania, gdzie pisał o złym traktowaniu przez policjantów czy spaniu „w sieniach”. Dzięki nim - niewykluczone, że przy wiedzy i akceptacji F. Stadiona - „nagroda cesarska”, mająca go wyróżniać z tłumu, niczym nie odbiegała warunkami od standardowych umów podpisywanych przez innych osadników na Bukowinie. Urzędnicy w ten sposób zemścili się na nim za pismo do cesarza, a może i inne sprawy.

Zakwestionowanie dokumentu przez Szelę było równoznaczne z odwołaniem się. 24 listopada 1850 r. urzędnik dworskiego ministerstwa finansów w porozumieniu z prowizorycznym zarządcą Bukowiny H. Henningerem zastanawiał się, czy po wydarzeniach roku 1848, wobec tak wielkich zmian w stosunkach poddańczych (m.in. zniesienie pańszczyzny), nie powinno się odstąpić od rozwiązań przyjętych we wcześniejszej umowie z Szelą. Sprawę pozostawiono jednak bez zmian ${ }^{205} .20$ czerwca 1851 r. namiestnik Galicji Agenor Gołuchowski poinformował więc oficjalnie Henningera, że Szela sam się zgodził na 10 lat wolnizny, więc nie ma możliwości zmiany uprzedniej decyzji ${ }^{206}$. W następstwie tego 20 grudnia 1851 r. w urzędzie kameralnym w Sołce Szela, zapewne pod presją okoliczności, skreślił krzyżyk i odcisnął palec na znanym nam już Publications-Protokoll ${ }^{207}$. Podpisał, ale nie pogodził się. W lutym 1853 r. w skardze przesłanej do cesarza na złe traktowanie przez zarząd kameralny w Sołce Szela nie omieszkał przypomnieć: „Także prześ. c.k. kancel. felwarteryczna państwa [zarząd komisaryczny] Solka każe mi podatek płacić z drugiemi, a ja mówiłem: Jakże ja mam płacić, kiedy mnie Najjaśniejszy monarcha z najłaskawszego rozporządzenia swojego podatek podarował? Na to dostałem odpowiedź: Pan Bóg wysoko, a Najjaśniejszy monarcha daleko, a ze mną będą podług swojego upodobania postępować. Ja Jakub Szela,

Dotations-Grundstücke übernehme, dieses Protokoll aber nicht fertigen werde", ÖStA, AVA, OPB, kart. 30, fasc. 5720/1854 „Jakob Szela”, Odpis niemieckiej wersji protokołu przejęcia ziemi przez Szelę w Glicie, 10 V 1848, Sołka 14 IV 1854 (załącznik do pisma W. Madurowicza do A. Gołuchowskiego z 26 VI 1854 nr 25373), k. 8, s. 1.

205 Brak oryginału decyzji, a informacja pochodzi z pisma W. Madurowicza do A. Gołuchowskiego z 26 VI 1854 (ÖStA, AVA, OPB, kart. 30, fasc. 5720/1854 „Jakob Szela", nr 25373, k. 9-10).

206 ДАЧО, kart. 1, fasc. 10567/1851, A. Gołuchowski do H. Henningera, 20 VI 1851, k. 1, s. 1-2.

${ }^{207}$ ДАЧО, kart. 1, fasc. 10567/1851, k. 7, s. 1. 
jako wierny sługa Najjaśniejszego monarchy, upadam i klęczę przed stopami z wielką bojaźnią Najjaśniejszego monarchy, i proszę, aby też tej mojej krzywdy ta prośba skutek otrzymać mogła"208.

Jeszcze wcześniej, w lipcu 1848 r., w czasie, kiedy prasa wyzwoliła się z cenzury, tarnowska „Zgoda” ${ }^{209}$ oraz lwowska „Gazeta Narodowa”"10 ogłosiły treść tego samego „konceptu” Jakuba Szeli, czyli listu, jaki rzekomo wysłał do cesarza. Chłop skarżył się tam na wybór na posła do Konstytuanty nie jego, ale chłopa Lukiana Kobylicy z huculskiej wsi Ploski nieopodal Wiśnicza. Protestował też, dowodząc, że to on jest na Bukowinie prawdziwym królem, a nie Kobylica, który w 1843 r. miał wystąpić przeciwko panom. „Gdybym był został wybrany - czytamy na szpaltach obydwu pism - mógłbym sobie z pieniędzy podróżnych 302 złr. niemniej z pieniędzy na dzienne utrzymanie po 200 złr. na miesiąc, nieco zaoszczędzić, a na sejmie mogłem wyśmienicie zasiadać". W grudniu 1848 r. redaktor „Gazety Tarnowskiej” („Zgody”) wrócił do sprawy ${ }^{211}$. Na doniesienia te zareagował wybitny badacz niemiecki Raimund Kaindl, uznając za fałszywe kwestie tyczące się Kobylicy ${ }^{212}$. Najprawdopodobniej ów list Szeli był spreparowany. W tamtym „gorącym” czasie nie brakowało jeszcze bardziej sensacyjnych doniesień dotyczących Szeli, z których do najbarwniejszych należało rzekome powieszenie się chłopa ${ }^{213}$. To budzące wątpliwości pismo mogło być echem jakiegoś nieznanego nam odwołania Szeli, które nie zachowało się do naszych czasów, ale jest to wątpliwe. Ktoś mający wiedzę, że nie jest on zadowolony z nadziału, umiejętnie, pod czytelnika żądnego sensacji, wynaturzył intencje chłopa. Z innych zachowanych listów Szeli wiemy, że nigdy nie występował on z roszczeniami tego typu,

208 Skarga Szeli do cesarza z 9 II 1853 r., „Dziennik Polski” (Lwów), R. 1, 75, 29 XII 1861, s. 3. Treść tego zażalenia podano w języku polskim, co jest z całą pewnością tłumaczeniem z niemieckiego, gdyż Szela wszystkie swoje prośby do władz wystosowywał w tym języku. W trakcie prac redakcyjnych nad niniejszą pracą tę petycję Szeli opublikował Bogusław Baczyński (Jakuba Szeli opisanie we wspótczesnej mu prasie, „Rocznik Tarnowski" 17, 2012, s. 25-27), nie opatrując jej jednak aparatem naukowym. W Tekach A. Schneidera, nr 1582, s. 275 (Archiwum Narodowe w Krakowie, oddz. Wawel) znajduje się notatka „Szela 1853. Trzy podania oryginalne do cesarza Jakuba Szeli: Lichtenberg. W Bibliotece Poturzyckiej, Miscellanea IV.16". W rozproszonych zasobach Biblioteki Poturzyckiej ze Lwowa, Krakowa, Wrocławia i Warszawy dotychczas nie udało się odszukać tych archiwaliów.

209 „Zgoda” 22, 29 VII 1848, s. 144 (4).

210 „Gazeta Narodowa” 74, 25 VII 1848. B. Baczyński (op. cit., s. 26-27), podobnie jak wcześniej, nie zadał sobie trudu jego analizy.

211 „Gazeta Tarnowska (Zgoda)” 15, 7 XII 1848, s. 58 [2].

${ }^{212}$ R.F. Kaindl, Die Bukowina in den Jahren 1848 und 1849, nadb. z „Österreichisch-Ungarische Revue" 25, 1899, s. 276.

${ }^{213}$ S-W, s. 110. 
nigdy nie żądał - zawsze przymilał się i prosił - list ów nie był stanowczo w jego „stylu”. To nie pierwsza i nie ostatnia mistyfikacja, jaka dotknęła znienawidzonego przez wielu chłopa.

W 1852 r. Szela wysłał do stolicy dwie skargi, a w 1853 kolejne cztery ${ }^{214}$. Mylił się, myśląc, że jego pisma do Wiednia nie dochodzą. Wszystkie jego zażalenia były skrupulatnie odnotowywane i nabierały rutynowego, choć powolnego biegu. 15 stycznia 1854 r. chłop znów upomniał się o swoje, tym razem pisząc do wysokiego c.k. Generalnego Inspektoratu Żandarmerii, czyli ministra Johanna Franza Kempena von Fichtenstamm. Ten unikalny dokument zachował się, przytaczamy go więc w całości:

Przepełniony najwyższym szacunkiem, jako poddany zaprawdę wierny na życie i śmierć naszego Najjaśniejszego Monarchy, polecając się wysokiej trosce i w oparciu o nią, odważam się wystosować tę najuniżeńszą prośbę, przedstawiając następujące powody: Pierwszy. Urodziłem się w pełnym szacunku, w Smarzowej w Galicji, gdzie posiadałem jako włościanin gospodarkę rolną, i przez pełne 24 lata byłem deputowanym tamtej gminy. Już na początku mojej pełnoletności zapłonąłem do mojego Monarchy niezłomną wiernością, co okazałem podczas całej mojej służby, zarówno w Smarzowej, jak też w okolicznych miejscowościach, zapisując się w pamięci każdego jako posłuszny i wierny państwu poddany. Rewolucyjny zamiar z roku 1846, gdzie wprowadzono w błąd chłopów, podżegano ich przez propagatorów, co uważam za największe nieszczęście, doszedł do moich uszu wystarczająco szybko, co zawdzięczałem niezwłocznemu powiadomieniu przez prześwietne c.k. starostwo tarnowskie, więc poczuwając się w obowiązku z narażeniem własnego życia starałem się temu zapobiec. Właśnie to sprawiło, że wrogo nastawieni zaczęli dybać na moje życie i z tegoż powodu sprawiedliwy rząd uznał za stosowne przenieść mnie z Galicji do Bukowiny. Przy moim odejściu z Tarnowa do nowego wskazanego miejsca, do Lichtenbergu w Bukowinie, zostało mi ze strony wysokiego c.k. starostwa zgodnie z rozporządzeniem rządowym polecone co następuje: Jakob Szela opuszcza swoją ziemię i domostwo w Smarzowej i udaje się wraz z rodziną do Bukowiny, dokładnie do Lichtenberg w dobrach kameralnych Solka, gdzie też zostanie mu oddane na własność po wsze czasy odpowiednie mieszkanie wraz zabudowaniami i 30 mórg gruntu, a to w taki sposób, że dzieci jego dzieci będą zwolnione na zawsze z jakichkolwiek danin $z$ wyjątkiem ustalonych podatków. [- - ] każdy poddany jest zobowiązany oddanie i wiernie służyć najwyższemu państwu. Krwią i ży-

214 ÖStA, HHStA, Kabinets-Kanzlei, Bittschriften Protokolle (dalej: KK-BP), 1852, skargi nr 10381 i 17747, 1853, skargi nr 2183, 4676, 16544 i 16545. Zachowały się tylko enigmatyczne wpisy w powyższych księgach protokolarnych, a większość zażaleń została zbrakowana. 
ciem świadczyć. I kładę się do grobu z żalem, że memu najłaskawszemu monarsze oddałem zbyt małe usługi jako prosty i niemajętny człowiek. Z powodu opisanych wyżej okoliczności, związanych ze złożonymi doniesieniami i z działaniem dla dobra ogółu, władza cywilna jest w przeważającej części nastawiona do mnie wrogo i to w tak wielkim stopniu, że brak mi ufności przedstawić moją prośbę, tak że pozwalam sobie tę uniżoną petycję przedłożyć Wysokiemu c.k. Wojskowemu Inspektoratowi Żandarmerii. Ad 1.: Wedle przedłożonego w załączniku protokołu, który posłusznie załączam [protokół z $10 \mathrm{~V}$ 1848] wynika, że jestem traktowany w ten sam sposób, jak inni koloniści z Lichtenberg, którzy również zostali obdzieleni 30 morgami gruntu, i nie jestem mniej od nich obciążony stale narastającymi należnościami, co nie jest zgodne z wysokim rozporządzeniem c.k. starostwa w Tarnowie. Ad 2.: Jako że wysoki Rząd okazał mi łaskę, przenosząc mnie wraz z rodziną do Bukowiny, prośba niżej podpisanego dotyczy jedynie tego, aby wysoki Rząd wydał najłaskawszą decyzję, potwierdzającą, do jakiego stopnia uznać można jego [Szeli] zasługi, aby tenże spełniać mógł swój obowiązek wobec władzy z największą dokładnością i punktualnością. Lichtenberg w Bukowinie, dom nr 33, Jacob Schela ${ }^{215}$.

215 „Hohe kk. General Gendarmerie Inspectoriat! Von dem höchste Gefühle beseht, als wahrhaft treuer Unterthan für unseren aller Gnädigsten Monarchen zu leben, und zustreben, wage ich in aller Unterthänigkeit meinen gehorsamste Bitte, dem aller höchsten Treue näher zurücken, und stütze solche auf folgende Gründe als [1tes] Binn ich ehrerbithigst aus Smarzowa in Galizien gebürtig, besaß als Landman dorten eine ganze Bauer-Wirtschaft, und war in demselben Orte als Deputierte durch volle 24.Jahre. Schon von Anbeginn meiner Volljährigkeit entbrannte in mir der Keim Meinem Monarchen unverbrüchlich Treue zu bewahren, was ich während meiner ganzen Dienstzeit dahin gestrebt habe, so wohl in dem Orte Smarzowa, als auch in den umliegenden Örter jedem Einzelnen einzuprägen dem allerhöchsten Staate treu und gehorsam zu sein. Der Revolutionäre Vorsatz vom Jahre 1846 kam mir zur rechten Zeit zu Ohren, was ich dem größten Unglücke hin von dem Hochlöbl. kk. Tarnower Kreisamte unverzügliche Anzeige erstattet habe, - und durch die Propaganten jrre geleiteten, und verführten Bauern selbst mit Aufopferung meines eigenen Lebens auf dem Weg der Pflicht zubringen eifrigst bemüht war. Dieß verursachte daß die übel gesinten nach meinem Leben zu streben Anfängen, weßhalb mich die Gerechte Regierung für gut fand aus Galizien in die Bukowina zuversetzen. Beim meinem Abgehen von Tarnow auf die neue Bestimmung nach Lichtenberg in der Bucowina wurde mir Seitens Hochlöbl. kk. Kreisamte folgendes bedeutet in Gemäßheit der hohen Regierung Erlasses verläßt Jakob Schela seine sämtliche eigentümlichen Grund und Hausbesitzungen zu Smarzowa und beginnt sich samt seiner Familie in die Bukowina respective nach Lichtenberg in der Caal Herschaft [Kameral-Herrschaft] Solka, allwo ihm eine angemessene Wohnung samt eben Gebäuden und 30 Joch reinen Grundes auf immer und währende Zeiten eingenthümlich gegeben werden wird, und zwar so daß seine Kinders Kinder außer der festgesetzten Steuerabgaben, von jeden anderen Gibiegkeiten auf immer befreit zuseyn sind. Hohe kk. General Gendermerie Inspectorat weit entfernt nur in entferntesten Sinne des Wortes mir Anmessungen auf etwaigen Verdiensten zu machen, Pflicht und Schuldigkeit ist jeden Unterthan dem allerhöchsten Staate ergebend und treu zu dienen. - Blut und 
13 lutego 1854 r. z Wiednia przyszło pismo od Kempena do Gołuchowskiego, aby wyjaśnił sprawę $e^{216}$. Zajął się nią w Namiestnictwie Wincenty Madurowicz $^{217}$, stwierdzając 28 czerwca 1854 r., że 4 grudnia 1853 r. prezydent bukowiński odniósł się do propozycji ministerstwa finansów w kwestii Szeli, gdzie wyraźnie określono, iż tenże dwukrotnie podpisał się pod spełnianiem zobowiązań o 10 latach wolnizny -14 grudnia 1847 r. oraz w roku 1851 - dlatego decyzja zostaje podtrzymana ${ }^{218}$. Namiestnik odpisał więc ministrowi, że skarga Szeli, jakoby jemu i jego rodzinie miano obiecać, iż oprócz należnych podatków, nie będą płacili jakichkolwiek świadczeń,jest bezpodstawna ${ }^{219}$. Nie wiadomo, czy Szela otrzymał odpowiedź, ale przez kilka najbliższych lat kwestia ta nie wypływała. Niepokorny chłop wróci jeszcze do niej w roku 1857.

„Na przestrzeni 30 mórg austriackich ${ }^{220}$, w jednej części gruntu znajduje się las i wzniesienie o bardzo korzystnym położeniu - zachwalał dotację jeszcze w sierpniu 1847 r. zarządca dóbr Johann Koch ${ }^{221}$ - naj-

Leben für dasselbe zu Weisen, - und nur mit dem Bedauern gehe ich Einsteins ins Grab meinem gnädigsten Monarchen als schlichter und unvermögender Mann zu wenig Dienste gethan zu haben. Aus Ursache meines obbezohenes Umstandes betreff nur erstattenen Anzeige, und mit Wirkung zum besten des Allgemeinen ist mir das Ziville überwiegend sehr feindsellig und zwar in dem Grade daß ich mich kaum vertrauen kann meine anliegende Bitte anzubringen, und erdreiste mich meine gehorsame Petition einem hohen kk. Militär Gendermerie Inspektoriate zu unterbreiten. [Ad 1] Laut im Anlage gehörsamst angeschlossenen Protokoll sub ./. [protokół z $8 \mathrm{~V}$ 1848] beweiset das ich die andere Colonisten von Lichtenberg welche gleichfalls mit 30 Joch Grundes betheilt sind, gleich gestellt binn, und nicht minder alle welche immer nahmen habenden Schuldigkeiten nicht Ausgenommen, daher dieses steht nicht im Einklange mit dem Hohen Erlasse der Hohlöbl. kk. Tarnower Kreismates. [Ad 2] Da die hohe Regierung die Gnade hatte mich samt meiner Familien in die Bucowina zu bestimmen gerührte, so basiert sich die Bitte des ehrfurchtsvoll Unterzeichneten lediglich darauf um von der hoher Regierung den gnädigsten Bescheid zu wissen, in wie ferne die Bestimmung seiner Leistungen bestehe, damit derselbe seiner Pflicht mit größten Genauigkeit und Pünktlichkeit ein für alle Macht nachkommen könne. Lichtenberg in der Bucowina am 15ten Jänner 1854, Jacob Schela zu Lichtenberg in der Bucowina Haus N 33", ÖStA, AVA, OPB, kart. 30, fasc. 5720/1854.

${ }^{216}$ Brak oryginału dokumentu; wzmiankowany jest w piśmie A. Gołuchowskiego do J.F. Kempena, 12 VIII 1954 (ÖStA, AVA, OPB, kart. 30, fasc. 5720/1854 „Jakob Szela”, nr 1074, k. 6, s. 1).

217 Ober-Finanzrath Valentin Ritter v. Madurowicz, w: Provinzial-Handbuch der Königreiche Galizien und Lodomerien für das Jahr 1853, Lemberg 1853, s. 85.

218 ÖStA, AVA, OPB, kart. 30, fasc. 5720/1854 „Jakob Szela”, nr 25373, W. Madurowicz do A. Gołuchowskiego, 28 VI 1854, k. 9, s. 2.

219 ÖStA, AVA, OPB, fasc. 5720/1854 „Jakob Szela”, nr 1074, A. Gołuchowski do J.F. Kempena, 12 VIII 1854, k. 6, s. 1-2.

${ }^{220}$ Szela otrzymał 17,28 ha ziemi. 1 morga dolnoaustriacka (Joch) $=1600$ sążni kw. = 57,554 arów (0,576 ha), SGKP, t. 6, Warszawa 1885, s. 677.

${ }^{221}$ Johann Koch - zarządca (Verwalter) Fonds-Herrschaften Solka, Illischestie, 
bardziej oddalony wschodni skraj posesji na całej długości przylega do drogi cesarskiej, gdzie wykarczowanych zostało tymczasowo 5 mórg, w przeciwieństwie do reszty, na której jest trochę krzaków i korzeni, ale ich usunięcie przy niewielkim nakładzie pracy nie powinno nastręczyć trudności. [- - ] Teren nadaje się bardzo dobrze na budowę domu, leżąc zaledwie niecałe 30 sążni ${ }^{222}$ od ostatniego zabudowania w Glicie; jeśli jednak zechce on zamieszkać we wsi, która liczy tylko 60 rodzin, częściowo Niemców, Mołdawian i Rusinów, udostępniona mu zostanie tam parcela o wielkości 1 morgi 1296 sążni"223. Ziemia była urodzajna i dogodna do hodowli bydła ${ }^{224}$, być może lepsza niż pod Tarnowem. Glit w roku 1843 liczył zaledwie 16 rodzin, które stanowiły zaczątek tej osady ${ }^{225}$, więc widać, jak szybko się rozwijał. Do kościoła i szkoły mieszkańcy musieli piąć się do położonego wyżej Fürstenthalu (Voievodeasa). W Sołce parafia założona została dopiero w $1856 \mathrm{r}^{226}$ Tam też mieścił się posterunek policji i żandarmerii oraz komora skarbowa. Należy wyjaśnić pewną rozbieżność. Pomimo że Szela wyjechał z rodziną do Glitu i faktycznie mieszkał na jego obrzeżach, to we wszystkich swoich pismach określał się jako mieszkaniec przylegającego do niego Lichtenbergu (Dealul Edri), z gruntu niemieckiej osady drwali powstałej w 1835 r. Podobnie figurował

St. Illie und Radautz, w: Schematismus der Königreiche Galizien und Lodomerien für das Jahr 1853, Lemberg 1853, s. 178.

${ }^{222}$ Klafter (pol. sążeń), miara długości określana według długości rozciągniętych ramion dorosłego mężczyzny. Niemal wszędzie w krajach niemieckich wynosił on 6 stóp (1,8965 m), Brokhaus Konversations-Lexikon, Berlin-Wien 1894-1896, t. 10, s. 386.

223 ,in der Ausdehnung 30 Joch enthält, in Theil eines Waldabschnittes ist, und eine ebene und sehr gute Lage hat; daß ferner der östliche Theil dieses Grundes mit der ganze Breite an die vorüberführende Kaiserstrasse steht, ein Theil von beiläufig 5 Joch bereits dermal rein ist und geackert werden kann; dagegen der übrigen Theil mit etwas Gestripp und alten Wurzelstücken besetzt ist, aber sehr leicht und mit geringem Aufwande rein gerodet werden kann. [- - ] wurde ihm bedeutet, daß dieses Gründstück zum Ausbau eines Bauernhofes ganz geeignet sey, indem solches kaum 30 Klaftern von dem letzten Wohngebäude des Dorfes Glitt entfernt ist, daß aber, wenn er es vorziehen sollte, in Dorfe selbst zu wohnen, das nur 60 Familien theils Deutschen, theils Moldauern und theils Ruthenen besteht, ihm fahrt an der Straße eine zum Hausbau und als Garten vollkommen geeignete Grundparzelle von 1. Joch 1296 Klaftren in die Dotation mitgegeben könne", ÖStA, AVA, PHSt, fasc. 1509/1848 „Jacob Szela”, Wstępne warunki przesiedlenia Szeli do Glittu, 26 IX 1847, k. 12, s. 1 nlb; 1 morga 1296 sążni, czyli niemal 2 morgi = ok. 1 ha.

${ }^{224}$ R.F. Kaindl, Das Ansiedlungswesen in der Bukowina seit der Besitzergreifung durch Österreich, Innsbruck 1902, Quellen und Forschungen zur Geschichte, Literatur und Sprache Österreichs und seiner Kronländer, t. 8, s. 453.

${ }^{225}$ J. Polek, op. cit., s. 41; W. Kosiul, Die Bukowina und ihre Buchenlanddeutschen, t. 1, Oberding 2011, s. 391.

${ }^{226}$ Według Johanna Polka (op. cit., s. 43) w 1857. Mógł to być błąd w druku, gdyż księgi metrykalne z Sołki prowadzono od $1856 \mathrm{r}$. 
w sołeckich księgach metrykalnych, czyli najwyraźniej tam jego siedziba po wybudowaniu została zakwalifikowana.

Szela zdecydował, że nie postawi domu w wiosce, ale poza nią, na przydzielonej parceli. Po przybyciu na Bukowinę zamieszkał tymczasowo w Glicie, naprzeciwko leśniczówki ${ }^{227}$.Zagwarantowany miał bezpłatny pobyt do czasu wystawienia domu, ale nie wiadomo, jak w praktyce to wyglądało, oprócz tego, że taka budowa mogła trwać do trzech lat ${ }^{228}$. Być może postąpiono z Szelą jak z innymi osadnikami - zamieszkał najpierw w drewnianej chacie (Blockhütte), aby przenieść się potem do murowanego domu ${ }^{229} . \mathrm{Za}-$ rządca Koch zobowiązany był dostarczyć mu materiałów budowlanych, czyli drewna, wapna i cegieł bez zapłaty, a na dodatkowe rzeczy związane z budową wystawić rachunek albo rozpisać je na raty (tzw. renta) ${ }^{230}$. Dom Szeli jest najlepszym przykładem, jak powstają legendy. W oczach Szydłoskiego, który nigdy nie był na Bukowinie, a cokolwiek wiedział, było zasłyszane najpewniej od Staszka Szeli, nowa siedziba ojca chrzestnego była niemal pałacem: „,budynki wielkie, było w domu z jednej strony 18 okien. Gnój wyrzucał do szkarpy spod bydła, bo mu nie trza było"231. W aktach wyraźnie jest jednak powiedziane, że miał on otrzymać pomoc w budowie zwyczajowych na Bukowinie pomieszczeń mieszkalnych i gospodarczych („einer landesüblichen Unterkunft, Wohn- und Wirtschaftsgebäude") ${ }^{232}$. 0 ile Szelę zapewne było stać na budowę wielkiego domu, bo przecież musiał dysponować gotówką, gdyż nikt chyba w to nie uwierzy, że podczas rabacji zachował się altruistycznie i nic sobie nie wziął, kiedy inni chłopi rąbali siekierami podłogi czy ściany dworów w poszukiwaniu ukrytych kosztowności i pieniędzy ${ }^{233}$, wątpliwe jednak, aby chałupa, nawet „króla chłopskiego", miała 18 okien, i to z jednej strony. Relacja Szydłoskiego to zapewne jeden z elementów legendy chłopskiej o Szeli, która zaczęła swój żywot już w 1846 r.

Znając pierwotne nastawienie bukowińskich właścicieli ziemskich, trudno się dziwić, że Szeli utrudniano życie. Zaczęło się od drobnych spraw: „Prosiłem prześwietnej c.k. kancelarii państwa Sołka o przezna-

${ }^{227}$ M. Janik, Zesłanie, s. 117.

${ }_{228}$ R. F. Kaindl, Das Ansiedlungswesen, s. 452.

${ }^{229}$ Ibidem, s. 453.

230 ÖStA, AVA, PHSt, fasc. 1509/1848 „Jakob Szela”, Wstępne warunki przesiedlenia Szeli do Glittu, 26 IX 1847, k. 16-17.

${ }^{231}$ Relacja chłopa, s. 309.

232 ÖStA, AVA, PHSt, fasc. 1509/1848 „Jakob Szela”, Wstępne warunki przesiedlenia Szeli do Glittu, 26 IX 1847, k. 12 nlb.

233 [L. Gorayska], Podług, s. 317; H. Bogusz oskarżał chłopów o kradzież 4000 fl. m.k. (Skarga H. Bogusza do cesarza), wiarygodność czego podważał Oficer (Das Polen-Attentat, s. 282); H. Słotwiński, Z krwawych dni. Wspomnienia z r. 1846, Przemyśl 1890, s. 33. 
czenie drzewa na opał, ale dostałem odpowiedź: gdy potrzebuję, abym sobie kupił; to gdy kupić chcę, to nie dostanę w tem miejscu kupić gdzie drudzy, ale w najdalszem i najniedostępniejszem miejscu", skarżył się Szela po kilku latach pobytu ${ }^{234}$. „Najjaśniejszy Panie! — pisał chłop Względem mojego pokrzywdzenia, które ponosiłem od wójta wsi Lichtenberg Scholera ${ }^{235}$ i pana föerstera Heidmanika wsi Mardzyna [Marzyna] ${ }^{236}$, gdy Najjaśniejszy monarcha przejeżdżał przez Bukowinę, podałem żałobę na to wszystko moje pokrzywdzenie, ale żadnej wiadomości nie otrzymałem i znowu podałem moją prośbę dnia 4. lipca 1852 i 2 . listopada $^{237}$, ale i tak na to żadnej rezolucji nie otrzymałem, ale przyczyna tego jest taka, że chociaż mnie przyjdzie prześwietne rozporządzenie od Najjaśniejszego monarchy, to żadnej wiadomości nie dostaję, ponieważ prześwietna ces. król. felwarteryczna kancelarja Solka ma na mnie wielką zawziętość - przez to że ja w Galicji podczas niespokojnego czasu rewolucji wszystkie moje obowiązki podług ustaw i woli Najjaśniejszego monarchy wypełniałem" 238 . Szela w latach $1852-1859$ wysłał do Wiednia co najmniej 9 próśb ${ }^{239}$. Zadumałby się jednak głęboko, gdyby wiedział, że jego petycje były jednymi z około 25 tysięcy, jakie wpływały rocznie do kancelarii dworskiej.

Z wielką bojaźnią upadam i klęczę przed stopami Najjaśniejszego monarchy i przedstawiam moje pokrzywdzenie w sposób następujący pisał niestrudzenie - Jako tenże wójt Marcin Scholer nabrał do siebie sześciu poddanych wsi Lichtenberg i przeszedł z niemi do mnie na mój grunt, a ja czyścił grunt z krzaków, wybili mnie i jeszcze siekierę odebrali - ale taka była przyczyna tego, że ja kazałem bydło tego wójta z mojego gruntu na jego odwrócić, ponieważ mi wielką szkodę narobiło w gruncie, ale względem takiego występku poszedłem do prześ. c.k. kan. Solka, ale zamiast czego zostałem jeszcze wyśmiany, a za kilka tygodni Marcin Scholer otrzymał władzę od państwa na wójta, ale ja potem jego bydło bałem się odganiać z mojego gruntu, chociaż mi największą szkodę robiło, bo przykaz dostałem od wójta, że gdy nie będę chciał pozwolić paść na swoim gruncie, to moje życie stracę. Jak mówił, tak akuratnie

${ }^{234}$ Skarga Szeli do cesarza z 9 II 1853 r.

235 ÖStA, HHStA, KK-BP, Skarga Szeli nr 2183 z 1853 r. Chodzi o wójta Martina Schallera. R. F. Kaindl, Das Ansiedlungswesen, s. 456-457.

${ }^{236}$ We wszystkich skargach Szela pisze „Heidmanik”. Mowa o Johannie Hetmaniku (Provinzial-Habdbuch der Königreiche Galizien und Lodomerien für das Jahr 1853, s. 179), leśniku pierwszej klasy w Marzynie w dobrach sołeckich, które z kolei podlegały k.k. Cameral-Forstbezirk w Gurahumorze.

237 ÖStA, HHStA, KK-BP, Dwie skargi nr 10381 i 17747 z 1852 r.

${ }^{238}$ Skarga Szeli do cesarza z 9 II 1853 r.

239 ÖStA, HHStA, KK-BP, $1852-2,1853-4,1857-1,1858-1,1859-1$. 
chciał zrobić; trafiło się za kilka dni, że z drugiej wsi Glitu przyszło bydło, a ja poszedłem jego odwrócić, będąc w tej nadziei, że mi wójt nie będzie nic mówił za cudze bydło z drugiej wsi; ale gdy tylko wójt mnie zobaczył, wziął z sobą trzech poddanych wsi Lichtenberg, i przyskoczyli do mnie i bili mnie, a gdy już wójt swoją laskę w drobne kawałki potłukł, przewrócili mnie na ziemię i bili mnie pniakami, kułakami i czem tylko chcieli, a jak mnie puścili, zaczęli bić mojego małoletniego syna; a ponieważ to było przy samym domu, ja dobiegnął do domu i zamknąłem się, a oni przybiegli i zaczęli drzwi łamać, ale gdy drzwi nie mogli rozbić, przyskoczyli do okna, ale przecie szczęściem było, że kilku żołnierzy szli drogą, tak oni odeszli, a ja blisko traktu mieszkam i widziałem człowieka, który cały czas patrzał z drogi, co oni ze mną zrobią; ale gdy oni odeszli i on w swoją stronę poszedł; ale ja wszystkich plag nie mogłem policzyć, mnie 30 a synowi 15, to te przysięgą potwierdzić jestem gotów, i potem kilka miesięcy niebezpiecznie chorowałem, a gdy znalazłem tego człowieka, imieniem Antoni Matusiak, wezwałem go do protokołu, aby prawdę zaświadczył, co widział w prześ. c.k. kan. Solka; ale gdy on mówił co widział, co robili ze mną, to państwo grozili mu karą i że jego z kraju precz wygonią, i niprzyczem zostało ${ }^{240}$.

Nie dysponujemy oryginałem prośby, więc nie można zweryfikować jej treści, ale przypuszczalnie Szela połączył tutaj dwie różne sprawy: wymierzenie jemu i synowi kary, odpowiednio 30 i 15 kijów przez wójta i jego ludzi, oraz drugiej, pobiciu przez nieznajomych. Na plagi poskarżył się cesarzowi w listopadzie $1852 \mathrm{r} .{ }^{241}$ Możliwe wydają się dwa scenariusze tego wydarzenia. Pierwszy, że wójt Schaller demonstracyjnie ukarał niepokornego poddanego i oddalił się ze swoimi ludźmi, a zaraz potem pojawiło się nagle trzech opryszków, którzy zaczęli bić Szelę i jego domowników, ale przepłoszył ich nadjeżdżający patrol wojska. Może na to wskazywać uwaga Szeli o mężczyźnie, który przyglądał się całej scenie z drogi, a potem zniknął. Naturalnie mógł on wyolbrzymić zajście z wójtem, „dopisując” wydarzenia, które nastąpiły trochę później, co jest drugą ewentualnością.

W tym samym miesiącu jak wójt dał innym przykład zabójstwa, a od państwa żadnej nagany nie miał - pisał Szela w tej samej skardze przyszło trzech mężczyzn w nocy i drzwi wyrębali i mnie śmiertelnie poranili siekierami, i moich domowników bili, i już mnie w pół śmierci odeszli, ale i tych by można znaleźć którzy to byli, aby tylko ta kobieta przysięgała, jako ona ich nie zna kto by byli, bo ona ich

${ }^{240}$ Skarga Szeli do cesarza z 9 II 1853 r.

241 ÖStA, HHStA, KK-BP, Skarga nr 17747 z 1852 r. 
widziała, bo w moim domu natenczas mieszkała, i ci byli przekupieni, a zatem państwo nie dozwala, aby ich ta kobieta przysięga wydała, którzy byli, bo ta kobieta ze wsi Glit, i ci byli bliżej jak ode mnie, ta kobieta poszła, to jej państwo wszelkie dobrodziejstwa wyświadczali ${ }^{242}$.

Tu już nie ma żadnych niejasności. Szelę i jego rodzinę świadomie pobito, o czym świadczy fakt, że nie został okradziony, gdyż na pewno nie zapomniałby o tym napisać. Zaczęły pojawiać się więc w jego życiu duchy z przeszłości, mściciel(e). Mogli być to ludzie nasłani przez Feliksa lub Henryka Boguszów, a może przez kogoś z rodzin innych ofiar pomordowanych w parafii siedliskiej. Pozostawienie Szeli przy życiu wydaje się logiczne - jeśli ktoś odczekał tyle lat, aby dokonać zemsty, uczynił to z zimną krwią - po co bowiem zabijać i dodatkowo obciążać sobie sumienie, kiedy można sprawić, że ofiara będzie cierpiała, żyjąc i rozpamiętując. Znamienne, że właśnie od najścia na dom Szeli zaognia się konflikt między nim a zarządem ziemskim. Może ktoś powiadomił lokalnych urzędników, kogo faktycznie mają u siebie?

„Wysokie c.k. rządy guberni Lwowa dali mi pozwoleństwo na trzymanie fuzji dla obrony swojego życia, ponieważ ja w cudzym kraju, i jeszcze dlatego mam wiele nieprzyjaciół dla mojego dobrego uczynku, którzy chcą mnie za to zgubić - żalił się Szela - ale podczas mojego odjazdu z domu, przytrafiło się w przypadku mojemu synowi, że na moim gruncie przy moim domu z tejże fuzji zastrzelił sarnca, i przez poddanych wsi Lichtenberg został zaraz oskarżony przed panem fersterem [leśniczym] Heidmanikiem wsi Mardzina, a on zaraz wziął do siebie 10 leśnych swoich i więcej z wsi, i przyszedł z nimi i obstawił wkoło mój dom z gwerami [bronią], tak jak na jakiego rabusia, a gdy ja do domu przyszedł, opowiadają mi ten wypadek, a ja zaraz udałem się do pana föerstera i prosiłem o przywrócenie mojej fuzji, bo zaraz pan föerster wziął z sobą tego sarnca i fuzję, a przychodzącą szkodę zaraz zapłacić chciałem, ale pan föerster nie żądał żadnej zapłaty, tylko za moją fuzję dubeltówkę 2 pistolety mnie dawał, a moja fuzja w wartości 40 zł. m.k., i poszedłem z niczem. Jako przez fuzji nie jestem pewny mojego życia, ponieważ mieszkam blisko lasu i do tego jeszcze mam wielu nieprzyjaciół" ${ }^{43}$. Zabicie „sarnca” to kolejny pretekst do wrogości. O oddanie cennej fuzji (skąd ją miał?) Szela upominał się w latach 1852-1853 aż czterokrotnie. Wreszcie w marcu 1853 r. zarządca stracił cierpliwość

${ }^{242}$ Skarga Szeli do cesarza z 9 II 1853 r.

243 Ibidem. 
i oficjalnie za kradzież dziczyzny wsadził Jakuba na 3 tygodnie, a Józefa na 8 dni do aresztu $^{244}$. Historia ze Smarzowej zaczęła się powtarzać, tyle że jego przeciwnikami stali się tym razem urzędnicy państwowi. Szela był jednak kuty na cztery nogi, znalazł więc i na to sposób. Zaczął kierować pisma do policji (żandarmerii), która - wiadomo - nie zawsze była przychylna cywilnym urzędnikom. Liczba petycji świadczyć może nie tylko o jego zapamiętałości, ale także o tym, że był on śmiertelnie przerażony. Skargi te musiały odnieść jednak skutek, gdyż przez kolejne trzy lata chłop nie napisał do Wiednia ani razu. Mogła też być inna przyczyna „ciszy” - integracja rodziny Szelów w tym nowym dla nich świecie - gdyż podobno zgermanizowali się oni kompletnie ${ }^{245}$. Zapewne nie było dziełem przypadku, że 18 czerwca 1865 r. Józef podpisał się pod petycją osadników niemieckich z Lichtenbergu do władz o zwolnienie $z$ prac leśnych ${ }^{246}$. Już jednak znacznie wcześniej, 19 lutego 1854 r., Józef zawarł związek małżeński z Kathariną Prosser ${ }^{247}$. Bardzo liczne potomstwo, którego się dochowali, w niemałym stopniu przyczynić się musiało do łagodzenia sporów. Pierwszym ich dzieckiem była najprawdopodobniej Paulina, urodzona ok. 1854 r. ${ }^{248} \mathrm{~W} 1856 \mathrm{r}$. przychodzi na świat Jakob, zapewne pierworodny potomek męski, co można wnioskować po imieniu honorującym sławnego dziadka ${ }^{249}$. Łącznie Józef i Katharina doczekali się nie mniej niż 10 dzieci i co najmniej 37 wnucząt ${ }^{250}$. W 1861 r. para ta została chrzestnymi rodzicami Piotra Śliwińskiego, syna Kazimierza i Józefy z domu Żukiewicz ${ }^{251}$. O zostanie drużbą poproszono Józefa w roku $1875^{252}$. Niekompletność ksiąg metrykalnych nie pozwoliła na dokładne prześledzenie tego wątku.

244 ÖStA, HHStA, KK-BP, Skarga nr 4676 z marca 1853 r.

245 O.M. Żukowski, Bukowina pod względem topograficznym, statystycznym i historycznym ze szczególnym uwzględnieniem żywiołu polskiego, Czerniowce-Lwów 1914, s. 44-46.

246 R. F. Kaindl, Das Ansiedlungswesen, s. 459.

${ }^{247}$ Józef poślubił Katharinę Prosser z d. Kaspara Prossera i Theresii z d. Schaller, ZGL, Bukowina, Fürstenthal, Katholisch, Getrennte 1843-1889, Trauungen, t. 3612 (2).

${ }^{248}$ Brak bezpośrednich śladów tego zdarzenia w księgach metrykalnych. Dnia 2 lutego 1875 r., w momencie ślubu z Martinem Schallerem (25), synem Martina, Paulina miała 21 lat, ZGL, Getrennte 1856-1908, t. 3795, nr 194.

${ }^{249}$ ZGL, Taufen 1856-1940, t. 3793.

${ }^{250}$ Ibidem, Eduard (1859), Carolina lub Cornelia (1861), Ludwig (1863), Albertina (1864), Michailina (1867), Ludwig (1870), Rosalia (1873) i zapewne po śmierci tej ostatniej córki jej imienniczka w 1875 r. Zarówno liczbę dzieci, jak wnucząt Józefa obliczono na postawie dostępnych, niekompletnych ksiąg kościelnych z Solki, bez uwzględnienia okolicznych miejscowości.

${ }^{251}$ ZGL, Taufen 1856-1940, t. 3793, nr 43 z 1861.

${ }^{252} \mathrm{Na}$ ślubie Jacobusa Hoffmanna i Theresii Schaller, ZGL, t. 3794, 4. 
W lutym 1857 r. zarząd dóbr w Sołce musiał przypomnieć się ze spłatą długu z 1848 r. za wykarczowanie 5 mórg ziemi, gdyż Szela napisał $\mathrm{w}$ tej sprawie kolejne zażalenie do Wiednia ${ }^{253}$. Nie znamy bliżej sprawy, ale znów musiało dojść do napięć, ponieważ w 1858 r. trafił on na 14 dni do aresztu, będąc - jak to nazwał - „prześladowanym przez zarządcę dóbr sołeckich". Prosił władze o zbadanie fałszywych pomówień wobec siebie, jakoby miał stwarzać zagrożenie dla innych ${ }^{254}$. Notatka jest zbyt lakoniczna, aby móc więcej wywnioskować. Chłop ten miał jednak nad wyraz niepokorną naturę, woląc w wieku 71 lat trafić do więzienia, niż ustąpić. W sierpniu 1859 r. - nie odpuszczając do końca - przesłał swoje ostatnie zażalenie do tronu, w proteście, że musi płacić za dawny karczu$n^{n} k^{255}$. R. Kaindl na marginesie opisu losów osadnictwa w Lichtenbergu i Glicie podał, że Szela w końcu otrzymał zwolnienie ze świadczeń, o które tak zawzięcie walczył ${ }^{256}$. Podpisanie przez Józefa wspomnianej petycji osadników, już po śmierci legendarnego chłopa w 1865 r., oznaczać mogło tylko jedno - udzielona ulga dotyczyła tylko i wyłącznie jego ojca.

W wątpliwość należy podać, czy wobec Szeli prowadzony był stały nadzór policyjny, o czym mówiła instrukcja z lutego 1848 r. ${ }^{257}$ Pierwotnie z pewnością miało to znaczenie, ale zaraz potem, kiedy ogłoszono uwłaszczenie i jego osoba stała się po prostu zbędna, musiało stracić na aktualności. $\mathrm{W}$ ani jednym $\mathrm{z}$ dostępnych $\mathrm{w}$ archiwach wiedeńskich dokumentów policyjnych za lata 1855-1861 Szela nie był wzmiankowany. Oczywiście informacje mogły mieć inną, utartą drogę urzędową, ale jest to bardzo wątpliwe.

Właściwie wszyscy badacze zajmujący się Szelą mieli rok jego śmierci 1860 - podany przez Józefa Wawel-Louisa.Jednak, jako że zanotował ją bez odnośnika do literatury, nikt temu nie dał wiary ${ }^{258}$. Szela zmarł 21 kwietnia 1860 r. Pierwszy informację tę zamieścił wydawany we Lwowie „Przegląd Powszechny”: „Dnia 21 kwietnia zakończył życie Jakub Szela, zamieszkały

253 ÖStA, HHStA, KK-BP, Skarga nr 3334 z lutego 1857 r., Szela „, bittet um ein angemessenes Aequivalent für ein, nach von ihm bewirkter Uibermachung eines im Jahre 1848 erhaltenen Grundes, abgerissenes Erdreich von 5 Joch".

${ }^{254}$ ÖStA, HHStA, KK-BP, Skarga nr 18261 z września 1858 r., Szela „,beschwert sich über die Verfolgung des Solkaer Bezirksvorstehers, und bittet um Nachsicht der ihm fälschlich wegen Uibertretung gegen die körperliche Sicherheit zuerkannten 14tägigen Arreststrafe".

255 ÖStA, HHStA, KK-BP, Skarga nr 11182 z sierpnia 1859 r.

${ }^{256}$ „Damals wurde auch die Grundentlastung des Ansiedlers Jakob Szela endgiltig durchgeführt", R. F. Kaindl, Das Ansiedlungswesen, s. 458.

${ }^{257}$ P. Rysiewicz, op. cit., s. 54; M. Janik, Zesłanie, s. 117.

258 „Charakterystyka Jakuba Szeli” z Pokłosia polskiego historyczno-literackiego J. Wawel-Louisa, S-W, s. 110. 
w kolonii Lichtenberg, po krótkiej, ale ciężkiej chorobie; opatrzony świętymi sakramentami z przykładną skruchą wybrał się do wieczności" ${ }^{259}$. Drugi odważył się ogłosić wiadomość krakowski „Czas”260. W dziennikach wiedeńskich „Presse”, rządowej „Wiener Zeitung” czy też „Gazecie Lwowskiej” nie pojawiła się nawet najmniejsza wzmianka. Interesujące, że wiadomość o śmierci Szeli powtórzył „Kurier Warszawski”261. Dopiero kiedy w 1861 r. nastąpiła w monarchii niewielka „odwilż” i pozwolono Polakom w Galicji na założenie nowych gazet, 29 grudnia 1861 r.w „Dzienniku Polskim” wydawanym od kilku miesięcy przez Franciszka Xawerego d'Abancourt, zbliżonego do Floriana Ziemiałkowskiego i Franciszka Smolki, wydrukowano znaną nam skargę z 9 lutego 1853 r., gdzie podany został rok śmierci Szeli. Zaraz powtórzyła tę wiadomość „Gazeta Warszawska”262, a nieco wcześniej redaktor paryskiego „Przeglądu Rzeczy Polskich” cierpko skomentował ten zgon: „Dzienniki austriackie donosiły, że umierał bardzo przykładnie, przyjąwszy przed skonaniem wszystkie sakramenta. Takie pojęcia religijne nie są nowością, ale rzeczą zupełnie utartą cechującą charakter rządów habsburskich"263.

Ponad rok po śmierci Szeli, 3 sierpnia 1861 r., zmarła jego małżonka Salomea ${ }^{264}$. Pochowana została w Sołce, ale raczej nie koło swego męża, gdyż nie odnotowano tego zdarzenia w sołeckich księgach metrykalnych ${ }^{265}$. Bezowocne dotychczas pozostały poszukiwania jego grobu. W literaturze przyjęło się, że Szela spoczął w Rudzie (Vicșani) pod Seretem (Sereth, Siret) ${ }^{266}$, jednak nie ma tam dzisiaj jego nagrobka ${ }^{267}$. Kolejne potencjalne miejsca pochówku: Sołka, Kaczyka i Fürstenthal wykluczyła analiza dostępnych ksiąg metrykalnych lub ich odpisów. Bezowocne okazały się poszukiwania dokumentów kościelnych z Rudy, co uniemożliwiło dalszą kwerendę ${ }^{268}$. Nie można bowiem wykluczyć, że proboszcz sołecki odmówił pochowania Szeli, więc Józef zawiózł zwłoki tam, gdzie inny ksiądz nie oponował. Oddalona o niecałe $50 \mathrm{~km}$ od Lichtenbergu

259 „Przegląd Powszechny” 35, 2 V 1860, s. 4.

260 "Czas" 104, 5 V 1860, s. 3.

261 „Kurier Warszawski” 121, 27 IV-9 V 1860, s. 670 [2].

262 „Gazeta Warszawska” 1, 2 I 1862, s. 2.

263 "Przegląd Rzeczy Polskich” 10, 10 X 1861, s. 40.

${ }^{264}$ ZGL, Sterberegister 1860-1940, t. 3797.

265 Odpisy wspomnianych ksiąg metrykalnych obciążone są błędami powstałymi przy ich przepisywaniu, nie można więc wykluczyć, że doszło do przeoczenia tego istotnego dla nas zapisu.

${ }^{266}$ M.in. PSB, s. 609.

${ }^{267}$ Według informacji C. Cehaniuc, przewodniczącej Stowarzyszenia Polaków w Kaczyce.

268 O wspomnianych brakach: „Der Südostdeutsche” 4, 15 IV 1992, s. 9. 
malutka osada polskich kolonistów w Rudzie jak najbardziej „wpasowuje" się w ten wariant. Sprawa pozostaje więc nierozwiązana, podobnie jak okoliczności zgonu Szeli, gdyż notatka z „Przeglądu Powszechnego” jest zbyt lakoniczna, aby wysnuć głębsze wnioski, poza tym, że nie został on zamordowany, ale zmarł śmiercią naturalną. Chociaż i tutaj mogła nastąpić ingerencja cenzury, która nie zezwoliła na napisanie prawdy, na co jednak nie udało się odnaleźć śladów w archiwach wiedeńskich.

Pomimo naświetlenia niektórych faktów z życia Szeli wiele kwestii nie zostało tutaj podniesionych. Konieczne wydaje się przede wszystkim dalsze „odmitologizowywanie” wizerunku tego przywódcy chłopskiego. Do najważniejszych wyzwań należy weryfikacja obrazu Szeli jako wzoru „pięknej lojalności", wątku najczęściej podnoszonego przez autorów niemieckojęzycznych. Również odnieść się trzeba do postrzegania Szeli jako Polaka.Czy pomimo wysławiania się w tym języku utożsamiał się on z polskością? Trudnych pytań jest więcej - próba ich analizy podjęta zostanie w powstającej właśnie monografii. Dzisiaj zaś z pewnością można stwierdzić jedno że jest za wcześnie na całościową ocenę życia Jakuba Szeli.

\section{Several Facts from the Life of Jakub Szela}

Jakub Szela, the "peasant king" of 1846, is undoubtedly one of the best-known and recognisable Polish peasants. His life, however, remains little examined in proportion to the popularity he enjoys, and even the precise date of Szela's death is undetermined. There are more unanswered questions: the number of wives and children, the circumstance of Szela's departure and sojourn in Bukovina, his army service and literacy. An issue producing emotional reactions among researchers involves unconfirmed information about a medal granted to Szela by the Viennese court for his part in the Galician peasant revolt. One could hazard, therefore, the opinion that the life story of this protagonist is immersed in myths and stereotypes. The article resolves the majority of the queries thanks to an extensive survey carried out in the archives and press of Austria, Poland, Romania, Germany and Ukraine. The collected material was subjected to a thorough analysis making it possible to establish facts from Szela's life. Consequently, after an almost sixty years-long interval the demythologisation of the "peasant king" has been intensified.

The article makes an essential contribution to the relatively least examined Polish national uprising of the nineteenth century - accomplished by the Polish democrats in 1846 - that unexpectedly ended with a bloody insurgence of the peasants.

Translated by Aleksandra Rodzińska-Chojnowska 